This item was submitted to Loughborough's Research Repository by the author.

Items in Figshare are protected by copyright, with all rights reserved, unless otherwise indicated.

\title{
Organizational transparency and power in firm ownership networks
}

PLEASE CITE THE PUBLISHED VERSION

https://doi.org/10.1016/j.jce.2018.07.001

PUBLISHER

Elsevier @ Association for Comparative Economic Studies

VERSION

AM (Accepted Manuscript)

PUBLISHER STATEMENT

This paper was accepted for publication in the journal Journal of Comparative Economics and the definitive published version is available at https://doi.org/10.1016/j.jce.2018.07.001

\section{LICENCE}

CC BY-NC-ND 4.0

\section{REPOSITORY RECORD}

Grosman, Anna, and Aija Leiponen. 2018. "Organizational Transparency and Power in Firm Ownership Networks”. figshare. https://hdl.handle.net/2134/34000. 


\title{
Organizational Transparency and Power in Firm Ownership Networks
}

\section{Anna Grosman ${ }^{1 a^{*}}$ and Aija Leiponen ${ }^{\mathrm{b}}$,}

\begin{abstract}
When public institutions do not support information disclosure and contract enforcement, controlling owners may compensate by setting up ownership networks that facilitate the exchange of resources and alignment of interests. We examine how firms' controlling owners draw power from ownership networks to provide access to resources for or to expropriate resources from their firms. Horizontal power originates from network centrality and is associated with resource access whereas vertical power originates from principal-principal agency conflicts and is associated with exploitation of minority shareholders. We highlight the impact of horizontal and vertical power through their interaction effects with transparency and disclosure (TD) practices on fixed investments and performance in Russian firms. We find that TD and horizontal power or connectedness are substitutes, while TD and vertical power are complements in their effects on fixed investment and firm performance. Without a strong commitment to TD, powerful owners may thus deprive the firm of productive investments.
\end{abstract}

JEL classification: G32, G34, P31, L14, L25

Keywords: corporate governance; ownership structure and networks; sources of power; transparency and disclosure; Russia.

\section{Acknowledgements}

We thank Gautam Ahuja, Janet Bercovitz, Sumon Bhaumik, Jun Du, Maria Guedes, Sergei Guriev, Bersant Hodbari, Olga Khessina, Tobias Kretschmer, Natalia Makarova, Thomasz Mickiewicz, Aldo Musacchio, Ilya Okhmatovskiy, Joanne Oxley, Ayse Saka-Helmhout, Ammon Salter, Simon Schillebeeckx, Anton Sobolev, Mike Wright, Anne ter Wal, Andrei Yakovlev, and Peter Zeitz for their insightful suggestions and comments. This paper has also benefited from the comments of seminar participants at Academy of Management (OMT Division), ISNIE (International Society for New Institutional Economics), EACES (European Association for Comparative Economic Studies), SEI (Strategy, Entrepreneurship and Innovation) Doctoral Consortium, Imperial College London, Aalto University, LMU Munich, National University of Singapore, Aston Business School, Copenhagen Business School, SOAS, University of London, Radboud University, University of Da Nang, Vietnam and University College London, UK.

\footnotetext{
1 * Corresponding Author: a.grosman@lboro.ac.uk, Tel. +44 (0)203 8051307

${ }^{a}$ Loughborough University London, The Broadcast Centre, Queen Elizabeth Olympic Park, London E15 2GZ UK

${ }^{\mathrm{b}}$ Dyson School of Applied Economics and Management, Cornell University, 351C Warren Hall, Ithaca NY 14853-7801 USA
} 


\section{INTRODUCTION}

In the absence of well-functioning financial and factor markets, governance arrangements may enable cooperation, resource exchange, and monitoring. Thus, governance influences both firms’ access to financial, knowledge, and political resources, and firms' vulnerability to the expropriation of resources by powerful organizational agents (Faccio, 2006, Frye and Iwasaki, 2011). We focus on the interaction between corporate governance practices and the power of owners. We highlight the implications of power asymmetries among major and minor shareholders, and information asymmetries between corporate insiders and outsiders.

In emerging economies, ownership tends to be highly concentrated (Enikolopov and Stepanov, 2013, Estrin, et al., 2009) and major owners of industrial companies often play visible roles in the economy beyond the companies they control (Frye, 2002, Hoffman, 2011). Such powerful owners may provide indispensable resources such as knowledge, connections, and funding, or they may discipline and monitor top managers to improve internal efficiency. However, they may also use their power to extract private benefits. We address the research question: when and how is the power of owners used for resource provision versus resource extraction? We approach this question empirically by examining the interaction effects of ownership and corporate governance practices related to transparency and disclosure (TD) on firm performance.

We focus on TD and ownership networks because they are critical in managing the institutional challenges arising from concentrated and opaque shareholding structures, frequent features of business organization in emerging markets. TD moderates information sharing between an organization and its external stakeholders. The ownership network of cross-holdings among major shareholders shapes resource provision via communication among the co-owners. We highlight the interaction effects of the ownership network and TD practices and argue that the importance of TD practices depends on the firm's position in the 
network of owners. Our main contribution is to distinguish those ownership network positions that enhance the ability of owners to provide resources to their firms from those that enable owners to expropriate resources from their firms.

We view power as a capacity of actors to overcome resistance on the part of other actors in order to achieve desired objectives (Dahl, 1957). We distinguish the two structural sources of power that actors can exercise on one another - horizontal power within a network of peers such as owners (Cook, 1977, Emerson, 1962), and vertical power within hierarchical relationships such as controlling vs. minority owners (Blau and Schoenherr, 1971). Horizontal power is measured as degree centrality: the more centrally a firm is positioned in a network of firms connected to each other via common owners, the higher is horizontal power it commands. Vertical power arises from the ability of the owner to influence strategic decisions of the firm in their control. Vertical power is indicated if there is only one major shareholder (and thus no other major owners act as a counterweight) or if an owner is a board member in the powerful lobbying association of Russian industrialists.

We develop hypotheses regarding the interaction of TD with horizontal and vertical power. Specifically, TD is expected to facilitate resource acquisition and utilization and hence enhance the ability of a firm to invest and to create value. Horizontal power also facilitates access to opportunities and resources. We thus hypothesize that horizontal power and TD are substitutes. In contrast, vertical power may enable expropriation of resources from the firm, whereas TD makes it more difficult for owners to draw private benefits. Therefore, we expect TD and vertical power to be complementary in enabling investments and good performance.

We empirically test our hypotheses regarding the implications of owners’ power with a panel dataset of large Russian listed firms. We utilize longitudinal information on firms’ TD practices collected by Standard and Poor's (S\&P) and cross-sectional information on 
firms’ major shareholders and their industry association ties, which we use to construct our ownership network measures. Much of related earlier research has utilized cross-sectional and single-industry surveys, while our dataset enables panel-data analyses and accounting for the major endogeneity concerns.

The Russian context is an excellent testing ground for our hypotheses. First, due to the high concentration of ownership in Russia (Guriev and Rachinsky, 2005), we are able to distinguish between the interests of the firm as a whole and the personal interests of the ultimate controlling owners, which the literature recognizes as difficult and relatively rare to achieve due to inherently complex ownership arrangements (Aminadav and Papaioannou, 2016). Second, the rich and diverse Russian ownership network lends itself to testing and extending social network theories in emerging economies (Aidis, et al., 2008). Third, Russia presents substantial variation in corporate governance practices both between firms and over the period of our study. Finally, the Russian economy is large, unique, and interesting in its own right (Puffer and McCarthy, 2011, Wright, et al., 2005), whereas empirical research on Russia is relatively scarce.

Our empirical analyses provide support for our hypotheses that horizontal power is a substitute for TD whereas vertical power is a complement in explaining investment in fixed assets or Tobin's Q, a measure of investment opportunities. We find that a higher TD score is associated with more investment and higher Tobin's Q, but this effect is observed only for poorly connected firms. Our interpretation is that centrality in ownership networks enhances access to resources, and that firms with such horizontal power need to rely less on TD to facilitate investment and performance. In contrast, vertical power of controlling owners can lead to agency costs and reduced investments and performance, but such behaviors can be mitigated by TD practices: a higher TD score leads to higher investment and Tobin's Q, but only for firms with a single major shareholder who is a board member in the powerful 
lobbying association of Russian industrialists. Transparent reporting practices thus may make it more difficult for managers or owners with vertical (hierarchical) power to draw private benefits (Liu and Magnan, 2011).

The rest of the paper is organized as follows. Section 2 introduces our hypotheses. Section 3 deals with data and empirical operationalization. Section 4 presents the methodology, while section 5 discusses empirical results. Section 6 concludes and elaborates on the implications of our study and future research.

\section{HYPOTHESES}

We propose a new empirical framework that explains how the power of major owners and corporate governance practices related to transparency and disclosure (TD) interact in creating desirable firm-level outcomes, measured by fixed investment and Tobin’s Q. First, we discuss how TD and the horizontal power of owners each individually impact fixed investment and Tobin's Q. Next, we outline how horizontal power moderates the relationship between TD practices and firm outcomes ${ }^{2}$. We then discuss how the vertical power of controlling owners influences firm outcomes. Finally, we analyze how vertical power moderates the impact of TD on firm outcomes. These hypothesized effects are summarized in Figure 1.

INSERT FIGURE 1 ABOUT HERE

\footnotetext{
${ }^{2}$ We use the term "moderation" in the sense it is used in statistical analyses in social sciences. The moderation model tests whether the prediction of a dependent variable from an independent variable differs across levels of a third variable, or moderator. Moderator variables affect the strength and/or direction of the relation between a predictor and an outcome, enhancing, reducing, or changing the influence of the predictor.
} 


\subsection{Transparency and disclosure (TD) and firm outcomes}

TD practices are a central and established element in corporate governance systems (Enikolopov, et al., 2014, Patel, et al., 2002). TD facilitates monitoring by reducing information asymmetries between insiders and outsiders, and, as such, it increases accountability and stakeholders’ trust in the organization (Aksu and Kosedag, 2006). TD practices may thus enhance the prospects for external finance and other resources (Black, et al., 2006). TD may also render internal operations more efficient, because it mitigates waste and expropriation by insiders. Our underlying assumption is that Russian firms generally need fixed investment. Official statistics and empirical research show that the Russian asset base is relatively old (Dzarasov, 2010), such that Russian firms are not likely to over-invest for empire building or other self-dealing reasons. A more transparent firm can thus be assumed to perform better in the long term via greater investments and stronger performance. H1 Adoption of more extensive TD practices leads to increased firm investment and Tobin's $Q$.

\subsection{Horizontal power of ownership networks and firm outcomes}

The ownership network is a critical aspect of the Russian economy. The patterns of private ownership in Russia have emerged and evolved as a response to a drastic change in the institutional environment, the collapse of the Soviet Union, whereby traditional formal agreements of economic exchange became difficult to enforce. With the significant weakening of law enforcement, much of the economy compensated by falling back on the old tradition of "blat," or extensive networking (Ledeneva, 1998).

As a result, the 2000s saw the emergence of a new trend in the relationships between major Russian firms and their key owners: the sole controlling ownership was no longer the modal type of ownership as alliances among major shareholders started to appear (Pappe and Antonenko, 2011). A famous example of such arrangement is the Alfa-Access-Renova 
business group, co-owned by three oligarchs, Viktor Vekselberg, Leonid Blavatnik and Mikhail Fridman. This network of owners arose as a result of acquisitions, disposals, and buy-outs of shares from old owners. Many key stock transactions were aimed at consolidating old informal relationships between the participants.

Ownership networks influence corporate behavior and governance. We first examine network positions that are likely to facilitate access to critical resources. According to the social network theory, firms that are more central in an exchange network are able to acquire more and higher-quality resources (Ahuja, 2000, Granovetter, 1974, Granovetter, 1985, Phelps, 2010), because networks structure collaborative and competitive activities (Wellman, 1983). In a two-mode network of firms and owners, firms can become central either by having multiple major shareholders or by having shareholders who control multiple major companies, or a combination of the two. Multiple major shareholders are likely to provide the firm with connections to diverse industrial partners and associated resources, whereas major owners with multiple companies may create more cohesive business groups that share the same interests and information about economic opportunities (Westphal and Khanna, 2003).

Diversified business groups or conglomerates have better access to international sources of capital, and add value by internalizing the functions of institutions that are missing in emerging markets (Khanna and Palepu, 2000), but there is also evidence of inefficiencies associated with business groups as their owners may pursue self-dealing and tunneling activities (Franks and Mayer, 2017). In contrast, firms whose sole owners control one or very few firms might suffer from limited access to capital, information or opportunities. While the literature on business groups suggests that they derive economic benefits because of their connections to the government or other business organizations, to our knowledge, this literature does not test for the effect of connectedness between the business groups or the positioning of a firm within the whole ownership network. Further, while the literature on 
business groups, and more broadly on corporate ownership and control (an in-depth overview of this literature is provided in Aminadav and Papaioannou, 2016), is primarily concerned with how the wedge between control and cash-flow rights due to pyramidal structures leads to expropriation of minority shareholders by controlling owners (Almeida and Wolfenzon, 2006, Burkart, et al., 2003, Dyck and Zingales, 2004, Masulis, et al., 2011), this literature devotes little attention to the power dynamics and connections between multiple controlling shareholders. A sole exception is the theoretical work of Bennedsen and Wolfenzon (2000) that examines how coalitions between controlling shareholders are formed to exert control. Neither does the literature on business groups tests how the position of business groups within the corporate network is impacted by TD practices.

Our setting is different from the literature on business groups as we are able to econometrically differentiate between firms that have a single owner or multiple controlling owners, and whether these owners co-own other firms with other owners, until we map out the entire ownership network of firms in our sample. For example, Norilsk Nickel was owned by two prominent Russian oligarchs, Vladimir Potanin and Mikhail Prokhorov as of 2005. Prokhorov also owned Open Investments, Polyus Gold, Quadra Power Generation, RUSAL, Yenisey River Shipping Company, all publicly listed firms in our sample. They share the same major shareholder, but that does not make them all part of the same business group. In fact, these companies are clustered into two business groups, Interros (e.g. Norilsk Nickel, Polyus, Open Investments) and Onexim Group (e.g. RUSAL, Quadra Power Generation, etc.). Furthermore, Vladimir Potanin, the other major shareholder in Norilsk Nickel, owned Krasnoyarsk Energo, Power Machines, Rambler Media, and TGC-14. These firms were not part of Interros or Onexim. However, these firms are all closely connected to each other through Potanin and Prokhorov. 
There are several benefits for a firm or its owner to be centrally positioned in this network of firms via their owners. First, a key benefit of centrality is being on the shortest path of information flow thus being faster at receiving and acting upon new information and opportunities (Bonacich, 1987, Freeman, et al., 1979). Well-informed and resource-rich firms are expected to perform better financially.

Second, central firms (for example those with several major shareholders) are better protected against pressure from government bodies than peripheral firms. It involves greater risks for a government agency or individual official to enter into a conflict with several major businessmen at once (Aidis, et al., 2008, Vries and Florent-Treacy, 2003).

Third, a central network position increases the ability of owners to promote the company's interests with the government and with industry peers because coalition building is typically more effective than influencing on an individual basis. Well-connected owners have a greater choice in selecting trusted associates as board members to facilitate dealings with the government, for example, to expedite permits and licenses (Melkumov, 2009). Also, the possibility of a reasonable compromise on a dispute between oligarchs is enhanced with centrality (Higley, et al., 1991). The 'central' core of the network can thus better mobilize itself to act in its own interest.

Finally, connectedness provides additional protection of assets because the owner of stakes in diverse companies is insured against sectoral risks. These are simple diversification benefits for the owners that enhance the ability of affected companies to make risky investments. Centrality thus facilitates the acquisition and retention of resources.

We now consider why owners of such firms are not likely to use their connections to extract rents from each other. First, resource extraction is most commonly related to expropriation of minority shareholders (Enikolopov and Stepanov, 2013). Our centrality measure is based on resource flows among controlling owners via firms they co-own and 
hence by definition does not directly relate to the resource extraction between minority and controlling shareholders.

Second, reciprocation and retaliation by the connected peers prevent a central owner from abusing peers’ privileges. In other words, this structure exhibits characteristics of an ‘old boys’ network’ where members enjoy high status (Bellavitis, et al., 2017) and support each other against outsiders (Edling, et al., 2012). Old boys' networks tend to coordinate and enforce the interests of their peers, rather than expropriation. For example, they may leverage political connections in developing new businesses, leverage other resources in entering new markets, provide access to capital and new technology, enable exchange of knowledge and managerial skills, and possibly redistribute profits to stabilize performance and reduce taxes.

Further, controlling owners must maintain their own reputation as power brokers. If battles for control between connected owners occur, they may result in one major owner being bought out by the other major owner or replaced with another (Pappe and Antonenko, 2011). In this case, the defeated owner simply exits the ownership network, so that at a given point in time, the link based on ownership is analogous to a relation of 'enforceable trust' (Kadushin, 1995). As a result, the ownership network is a relatively stable arrangement. Although each oligarch may make new acquisitions and/or gain new partners, the ownership network can take several years to form, and it is deeply embedded in Russian institutional and cultural norms and traditions and therefore possesses significant inertia.

The kind of trust important here is not formed dyadically, but rather represents "the web of social networks of the entire community" (Portes and Sensenbrenner, 1993), and is developed through repeated business interactions allowing little opportunities for outsiders to penetrate such a network (Aidis, et al., 2008). Embeddedness in the cohesive inner core of such networks through multiple interactions or 'deals' results in further reinforcement of trust. Thus, network centrality can be regarded as a structural source of interorganizational or 
'horizontal' power attached to an owner's position in the network (Astley and Sachdeva, 1984, Cook, 1977, Emerson, 1962) as opposed to power derived from the control of resources within a specific dyadic relationship ${ }^{3}$.

Central firms whose owners are highly embedded in the network of the industrial super elite are also likely to benefit from the mutuality of networks (e.g. Holm, et al., 1999). Such interdependence among overlapping owners and their firms can be viewed as credible commitments analogous to economic "hostages" (Williamson, 1983) that have been found to support exchange (Ahmadjian and Oxley, 2006, Pisano, 1989). Firms with highly networked owners may therefore be better able to enforce their contracts.

Thus, we expect that central firms are likely to invest more and perform better than poorly-connected firms in the ownership network:

H2 Horizontally powerful (central) firms exhibit greater investments and Tobin's Q.

\subsection{Horizontal power as a moderator of the relationship between transparency and disclosure and firm outcomes}

Per Hypothesis 1, we expect TD practices to facilitate access to external resources by reducing information asymmetries about the firm's internal operations. Therefore, TD is likely to be relatively redundant for well-connected and, consequently, well-resourced firms. Thus, we hypothesize that centrality in the ownership network and TD practices are substitutes: owners with horizontal power may already be able to obtain many of the resources needed, and hence advanced TD is not necessary to improve investments. In an institutional environment based on connections for resource-provision, connected owners may well choose to maintain the information asymmetries between internal and external

\footnotetext{
${ }^{3}$ It is true that access to multiple resource flows through network position will affect an owner's ability to generate dependencies through dyadic resource exchange, but this overlapping does not annul the conceptual distinction we are making here.
} 
parties and not rely on transparency for resource access. In fact, extensive TD practices may be in a direct conflict with trust-based peer networks that rely on a strict distinction between insiders and outsiders. Given that business practices in Russia typically reflect traditional cultural mistrust of formal institutions and outsiders (Puffer and McCarthy, 2011), a reliance on close personal networks among well-connected firms can reduce transparency and disclosure. Moreover, the effect of horizontal power in the ownership network might be less beneficial when TD is strong. For example, increased transparency may be used by outsiders to undermine the connected firms or even take over their assets (Lazareva, et al., 2009).

In contrast, we expect TD practices to be valuable to peripheral firms whose owners can provide only limited access to external resources. For these firms, risks of TD are outweighed by the benefits of enhanced resource availability through internal and external markets that rely on publicly available information to assess the quality and efficiency of the firm. These moderation arguments are summarized in our third hypothesis:

H3 Horizontal power in ownership networks reduces the positive effect of transparency and disclosure practices on firm investments and value.

\subsection{Vertical power and firm outcomes}

Agency theory, with its emphasis on consideration of moral hazard, is particularly relevant in firms and environments where the potential for managerial opportunism is heightened (Filatotchev and Wright, 2011, Jensen, 1986). In emerging economies, majority control is associated with particularly low levels of outside monitoring, because managers and controlling shareholders effectively collude to keep outside influence low, and the legal rights of minority shareholders are difficult to enforce (Filatotchev, et al., 1999). Hence controlling shareholders are inclined to appropriate corporate resources at the expense of minority shareholders. Such principal-principal agency (PPA) problems waste resources and may 
orientate the firm's behavior toward short-term and private benefits of the controlling owner instead of long-term collective benefits of all owners.

We introduce the concept of hierarchical or vertical power as the product of formal or informal authority (Peabody, 1962), whereby owners are able to extract resources from the focal firm. Vertical power (Blau and Schoenherr, 1971) is rooted in the hierarchical relationships between organizational actors. It manifests as the power asymmetry between the 'superior', here, controlling owner, and the 'subordinates', or minority owners. Due to asymmetric information and decision rights between controlling shareholders and minority shareholders, the former may exercise vertical power over the latter to pursue private benefits. We categorize as vertically powerful owners those controlling owners who are members of powerful lobbying associations or state affiliates. In an institutional environment where business-state relations are essential for survival, such affiliations can provide owners with opportunities to derive significant private benefits (Sun, et al., 2016). When a controlling owner has uncontested access to industrial resources, they are likely to have disproportionate influence within their corporate structure with respect to lesser shareholders ${ }^{4}$.

Vertically powerful owners can also be sole controlling owners who are not monitored by other major owners and hence have a higher tendency for self-dealing. Thus, when the firm has one single controlling owner or a politically powerful owner, collectively

\footnotetext{
${ }^{4}$ While we are interested in measuring the relative power of an owner (via their ability to influence policies through lobbying) in relation to other owners, there exist a large body of literature on politically connected firms (Faccio, 2006), i.e. firms where board and/or management members are politicians or affiliated with politicians. Although many scholars perceive a facilitative role of political connections (Faccio, 2006), including in studies on Russia (Szakonyi, 2016), extant empirical findings have shown inconsistent results concerning the impact of political connections on firm performance - ranging from positive (e.g. Cooper, et al., 2010, Frynas, et al., 2006, Hillman, 2005) to an inverted U-shaped (Luo and Chung, 2005) and to negligible or negative (e.g. Aggarwal, et al., 2012, Okhmatovskiy, 2010, Sun, et al., 2010). Thus, whereas political connections are an important aspect of economic activity in many emerging economies, their impact may depend on other factors such as corporate governance practices and ownership structures that are the focus of our study.
} 
defined as 'vertically powerful owners,' PPA costs are likely to be higher relative to those in firms with multiple controlling owners who are able to monitor each other (Laeven and Levine, 2008, Lins, 2003).

Such PPA costs imply that fewer resources are available for investment opportunities. Therefore, we expect that powerful owners reduce firm investment and Tobin’s Q:

H4 Firms with vertically powerful owners have lower investments and Tobin's Q.

\subsection{Vertical power as a moderator of the relationship between transparency and disclosure and firm outcomes}

Transparency and disclosure mechanisms allow the minority shareholders to monitor the majority shareholder more effectively. Comprehensive TD practices may thus enable the firm to commit to accountability and maximization of long-term returns. Therefore, firms with a vertically powerful controlling owner may choose to improve their TD practices to maintain internal efficiency and the confidence of external stakeholders. Better TD practices therefore counteract the PPA conflicts created by such powerful owners (Liu and Magnan, 2011). Whereas we argued that TD has a positive effect on firm performance, this effect will be larger when firms have vertically powerful owners. On the other hand, vertically powerful owners may have a detrimental effect on firm outcomes unless the firm is able to commit to accountability and transparency through corporate governance. It follows that TD practices and owners with vertical powers are complementary in their effects on firm outcomes, as measured by investment and Tobin’s Q:

H5 Vertical power of owners enhances the positive effect of transparency and disclosure practices on firm investment and value.

In summary, our framework highlights the conditions under which ownership networks may alleviate resource constraints by reducing information asymmetries and by enhancing the 
enforcement of exchange agreements, and those under which vertically powerful shareholders may exploit information asymmetries and their ability to influence to extort resources. In the former case, TD practices are a substitute, and in the latter case, TD practices are a complement with respect to the firm outcomes of investment and value creation.

\section{DATA AND EMPIRICAL OPERATIONALIZATION}

We use a unique ownership network dataset that links Russian public firms to their oligarch owners ${ }^{5}$ and the state. The unit of analysis is firm $i$ at time $t$. We analyse how measures from this network of owners, directly and through interaction effects, impact firm outcomes. The Russian context is appropriate for such a study, because there is great variation across companies and time in corporate governance practices, including TD.

Our sample includes about 100 of the wealthiest Russian private owners, each of whom has a major stake in at least one publicly-listed firm. We collect data on Russian firms publicly listed in Russia or abroad, and for each of these firms we identify controlling shareholders, including federal government, regional government, politicians and oligarchs.

Oligarch-owned firms are often structured as pyramids or through crossshareholdings. In these structures, the oligarch achieves control of the constituent firms via a chain of ownership relations (Guriev and Rachinsky, 2005). We dissect this relationship to expose the oligarch, i.e. the ultimate owner of the operating assets. The oligarch's shares are also frequently held on his behalf by a nominee in order to secure the oligarch's corporate and financial anonymity. Therefore, it is often the name of the nominee, not that of the oligarch, that appears on share registrars and accounts. We collected information on the ultimate owners identified through annual reports and other disclosures, interviews with

\footnotetext{
${ }^{5}$ Guriev and Rachinsky (2005) provide an extensive review on oligarchs, their business groups and their role in the Russian economy
} 
finance professionals close to the oligarchs’ firms, media publications (Vedomosti, Expert, Finance, and Kommersant), and business associations. This was a laborious task and required manual checks, but our approach is consistent with the one recently taken by other scholars facing missing and inconsistent information on ultimate ownership (Aminadav and Papaioannou, 2016, Chernykh, 2008).

We also collected information about the major shareholders' memberships in the board of the Russian Union of Industrialists and Entrepreneurs (RSPP according to the Russian acronym). This industry association is the most powerful lobbying organization that brings together politicians and oligarchs (Hanson and Teague, 2005). We obtain the TD scores from Standard \& Poor's for the period of 2002 - 2009. Finally, standard financial and accounting data are collected from Compustat Global. As a result, we have a panel of financial and TD information for 2002-2009 and cross-sectional information on their ownership networks and industry association memberships in 2005.

\subsection{Dependent variables}

We measure firm outcomes through Tobin's Q and through investment in fixed assets. While both types of measures are correlated with long-term performance of firms, they highlight different aspects of performance. To measure overall financial performance while incorporating sources of value not fully captured by accounting data (e.g., intangibles), we used market-to-book ratio or Tobin's $Q$ which is computed as the total market value of assets divided by the book value of assets. It is an indicator of expected return on equity and hence incorporates future market expectations about firm-level performance.

Our second dependent variable, investment, refers to the firm's annual capital expenditures to acquire or upgrade physical assets such as equipment, property or industrial buildings. Investment is provided by Compustat Global database through the Wharton 
Research Data Services (code: capx) and is normalized according to Russian accounting principles, disclosure methods and specific data items definitions. This variable is measured in natural logarithms.

Development scholars see fixed investment as essential in helping emerging economies catch up to advanced, industrialized economies (Inoue, et al., 2013). Scarcity of capital to fund promising fixed investments has long been emphasized as a major constraint of firm growth and performance in emerging economies (Cimoli, et al., 2009). Using investments to measure whether firms prioritize long-term productivity (Inoue, et al., 2013), jobs, growth, and profitability (De Long and Summers, 1991) is justified in the Russian context, because it is reasonable to assume that there is scarce investment. Capital investment by Russian firms is generally low and production assets are deficient in quality (Dzarasov, 2010). The current average longevity of equipment in Russia is twice its desired levels. Despite the prolonged recovery in 1999-2008, capital investment by Russian firms is still low and of poor quality. Political uncertainty and a fluid institutional environment gave oligarchs an incentive structure that induced a preference for asset stripping over long-term investment (Braguinsky, 2009, Braguinsky and Myerson, 2007, Campos and Giovannoni, 2006). Therefore, we argue that it is unlikely that any Russian firm would systematically make unnecessary investments which would reduce the validity of this dependent variable.

We measure investment in fixed assets through their book value. However, one of the forms of tunneling is to "overinvoice" and thus exaggerate the value of imported materials and equipment. Most new equipment is imported into Russia, as local manufacturers are not competitive on price or quality. Imported equipment in Russia is subject to substantial custom duties. Hence Russian firms favor importing cheaper or second-hand equipment to minimize the book value and custom duties. These custom regulations make overinvoicing inefficient relative to other types of expropriation. Nevertheless, to assess the possibility of 
overinvoicing, we collected information on firms' auditors. All firms in the sample except five are audited by internationally recognized auditing firms, providing their certification that assets are captured at their market value (Alon, 2013). Dropping the five unaudited firms from our sample does not affect our results.

\subsection{Independent variables}

Our key explanatory variables include the TD score published by Standard \& Poor's credit agency for the largest and most liquid publicly traded Russian companies in the period of 2002-2009. TD scores are available for 90 firms in 2009 and 149 firms in the whole 20022009 period, producing an unbalanced panel.TD is an important component of the corporate governance framework (OECD, 2004) and a leading indicator of corporate governance quality (Aksu and Kosedag, 2006). Beekes and Brown (2006) find that firms with higher overall corporate governance standards make more informative disclosures. Black, et al. (2006) analyze the various measures of corporate governance in Russia and conclude that sophisticated governance indices are not necessarily better predictors than TD scores. TD data have also been used in scholarly cross-country studies that assess the relationship between accounting transparency, country-level institutions, and economic performance (Enikolopov, et al., 2014, Hope, 2003, La Porta, et al., 1999).

Standard and Poor's uses two criteria to select the companies: size and liquidity. The liquidity of stocks is positively correlated with the size of the company, but there are exceptions, especially in cases of minor free-float. On the one hand, as the larger companies tend to be more transparent than smaller ones, our sampling method is likely to cause an upward bias in assessing transparency of the entire population of public Russian companies. On the other hand, as the companies included in the sample account for about 80 percent of the cumulative capitalization of the Russian stock market, they represent a large majority of the Russian economy in terms of industrial assets and operations. 
To assess owners' horizontal power, we analyze two-mode inter-firm networks where firms are linked to each other through a major shareholder. For example, if shareholder A owns a controlling stake in company $\mathrm{X}$ and a controlling stake in company $\mathrm{Y}$, then companies X and Y are connected to each other. Further, if owner B has a stake in firm X, then owners A and B are connected to each other. We assume an owner is controlling if he holds at least 10 percent of the share capital, but most controlling owners in the sample hold over 50 percent. About a quarter of all firms have multiple controlling owners. Most have two controlling owners; 11 firms have three such owners, and two firms have four or more controlling owners. 23 firms are controlled by both the state and one oligarch. The single owner variable equals 1 for firms with a single controlling owner and 0 for firms with multiple controlling owners. The ultimate ownership and membership data are extremely costly to retrieve, and older data are not available (however unlikely to be significantly different over our studied period). As a result, network measures are available only for a cross-section, and we can estimate the effect of network measures only through crosssectional or interaction specifications.

We focus on measures of centrality because the Russian network of controlling owners is relatively sparse, and more complex network measures are not very informative in this context (see Figure 2 for the 2005 whole ownership network).

\section{FIGURE 2 ABOUT HERE}

We project our two-mode network of firms and their owners onto a one-mode network of firms using UCINET 6 (Borgatti, et al., 2002). We dichotomize the matrix to $(0,1)$, where 1 represents the existence of an ownership tie between firms. Then we calculate the normalized degree centrality, which is the number of connections to other firms through the controlling owners of the focal firm divided by the maximum possible number of 
connections. We provide a simple hypothetical example with a few nodes, which illustrates the original two-mode network of firms and their owners and how it projects into a one-mode network of firms as well as how the degree centrality for each firm is computed. If shareholder A owns 45\% of Company X and 60\% of Company Y; and shareholder B owns 45\% of Company X and 70\% of Company Z (two-mode network of owners and firms), then Company X is connected to both Company Y and Company Z. Normalized degree centrality of company $\mathrm{X}$ is the number of $\mathrm{X}$ 's ties divided by the maximum possible number of connections or $2 / 2=100 \%$. X is central (horizontally powerful).

\section{FIGURE 3 ABOUT HERE}

To test hypotheses 2 and 3, we utilize this variable in a binary form where the indicator variable equals 1 if the firm's connectivity is greater than the mean (central firms), and 0 if it is less than the mean (peripheral firms). We use the mean as a cutoff, because it represents the underlying bimodal distribution of our data. We formed other network indicators but found that in our relatively sparse ownership network, the most relevant variation is captured by simple degree centrality. The degree centrality has a bimodal distribution, with a clear cut-off between low and high degree centrality. Therefore splitting the degree centrality at the mean captures this unique distribution of the data.

We also determine whether a firm is owned by a board member of the main Russian business association, Russian Union of Industrials and Entrepreneurs, or RSPP by the Russian language acronym ${ }^{6}$. The binary variable $R S P P$ thus indicates firms whose controlling owner is a board member of the industry association and is a proxy for vertical power. RSPP board members use the association as a vehicle to collectively lobby public authorities to

\footnotetext{
${ }^{6}$ Hanson and Teague (2005) provide an in-depth historical analysis of RSPP since its foundation in 1990
} 
influence the legislation and other policy decisions for matters of general importance to their businesses, such as tax breaks and land market reforms, but often in favor of their personal interests and at the expense of other smaller shareholders ${ }^{7}$. Business-state relations through RSPP and President Putin's official engagements with the RSPP congress are documented in the literature (Hanson and Teague, 2005). There are about 150 board members, who are selected every four years by invitation by the existing board as key "players" in the Russian economy (Frye, 2002). RSPP has over 328,000 members. Although industry associations are non-profit organizations serving the interests of their members to achieve coordination and cooperation (Leiponen, 2008), a major shareholder who is a board member of RSPP is likely to have superior (vertical) power over other oligarchs. Thus, although the RSPP membership is likely to generate access to valuable resources, it may also signal the presence of agency hazards due to unusual vertical power.

In order to test hypotheses 4 and 5, we create mutually exclusive and collectively exhaustive dummies for the combinations of potentially agency-cost-inducing ownership positions to measure vertical power of the owners. We assume that when a firm has a single controlling owner who is also a board member of RSPP, it is the most vulnerable to expropriation. The firm may also be somewhat vulnerable to expropriation if it has a single controlling owner who is not an RSPP board member, or if it has multiple controlling owners, at least one of whom is an RSPP board member. In contrast, we expect that firms that have multiple controlling owners, none of whom are RSPP board members, are the least vulnerable to expropriation by such owners. We also create such combinatory dummies for the interaction between the state and the single controlling owner.

\footnotetext{
${ }^{7}$ We do not capture political connections in a sense of direct tie to the state, formal or informal, but they are also accounted for in the RSPP membership, as a politically-connected RSPP member is expected to be more successful in lobbying. 36 firms (or $86 \%$ of the sample) with RSPP board membership are oligarch-owned, and the remaining $14 \%$ have a controlling stake by the state.
} 


\subsection{Control variables}

We use the variable Sales, expressed in natural logarithms, to control for firm size and financial resources that have been found to influence performance (Mairesse, et al., 1999). EBIT margin is the ratio of earnings before interest and taxes over sales. Debt is a long term interest bearing debt. Cash-flow is gross cash flow which is defined as the sum of net income before extraordinary items and depreciation and amortization. Dividends/ assets ratio is calculated as cash dividends over total assets. Foreign exchange is a binary variable indicating whether a firm is dual-listed on a foreign stock exchange (1) or not (0). We control for fixed effects, i.e. unobserved heterogeneity that is constant over time. In particular, fixed effects control for the effects of state ownership, as this is a permanent characteristic of firms in our sample. We also allow for macroeconomic changes over time by including year dummies in the model.

Tables 1 and 2 present the descriptive statistics and Spearman’s rank correlations among the estimation variables. Investment is positively correlated with firm size (sales), TD score, the number of owners, and RSPP membership. Tobin's Q is negatively correlated with firm debt and state ownership, and positively correlated with dividends ratio and a profitability ratio (EBIT margin). Centrality in the ownership network is positively correlated with investments, but is negatively correlated with Tobin’s Q, TD scores and not correlated with RSPP membership. More central firms thus tend to be less vertically powerful and pay less attention to transparency and disclosure. This means that an owner that is a board member of RSPP is not any more likely than other owners to control many firms or co-own firms with other controlling owners. Thus, the power gained through RSPP membership may substitute for being central in the ownership network. Hence, we do not empirically observe a significant overlap between horizontal and vertical powers. Further, state ownership is negatively correlated with TD, while a foreign listing is positively correlated with TD. In 
summary, higher TD scores are associated with a lower centrality in the ownership network and with a single controlling owner. State ownership and centrality are positively correlated which is in line with the literature on the role of state in the Russian economy (Enikolopov and Stepanov, 2013), as connections to the Russian government provide access to resources, property rights stability and financial support. These correlations are aligned with our hypotheses and the empirical results below.

INSERT TABLES 1 AND 2 ABOUT HERE

\section{METHODOLOGY}

\subsection{Dependent variable - Investment}

Our approach to estimate Investment follows the accelerator model in error-correction form by Mairesse et al. (1999) and Bond et al. (2003). Most research shows that investment is nonstationary, so error correction is desirable (Bean, 1981). Such models have been extensively used for capital investment and R\&D investment (Bean, 1981, Becker and Hall, 2009, Bond, et al., 2003, Mairesse, et al., 1999). An error-correction accelerator model allows separating the long run determinants of investment from short-run investment dynamics. We can thus assume that sales and investment are proportional in the long run, as in the simple neoclassical model, although in the short run their relationship may be more complex. We thus rely on the literature (Bond, et al., 2003, Driver, et al., 2005) to build our empirical specification:

$i_{i t}=\beta_{0}+\beta_{1} i_{i, t-1}+\beta_{2} \Delta s_{i t}+\beta_{3} \Delta s_{i, t-1}+\beta_{4}\left(k_{i, t-2}-s_{i, t-2}\right)+\beta_{5} X_{i t}+d_{t}+\epsilon_{i t}$

where $i_{i t}$ is the natural logarithm of fixed investment ${ }^{8}$, and $\Delta s_{i t}$ and $\Delta s_{i, t-1}$ are current and lagged differences of sales in natural logarithms. The term $\left(k_{i, t-2}-s_{i, t-2}\right)$ is the error

\footnotetext{
${ }^{8}$ The literature on investment contains a wide disparity of specifications. Different models of investment in the literature use different dependent variable formulations. The original econometric literature of (Jorgenson, et al.,
} 
correction term, where $k_{i, t-2}$ is the natural logarithm of the desired capital stock for firm $i$ in period $t-2$ and $s_{i, t-2}$ is the natural logarithm of sales for firm $i$ in period $t-2$. The error correction term represents the long-run properties of this model. 'Error correcting' behavior requires that $\beta_{4}<0$, so that a capital stock above its desired level is associated with lower future investment, and vice versa (Bond, et al., 2003).

To investigate the roles of TD and horizontal or vertical power variables, we include an additional vector $X_{i t}$ that represents such explanatory variables. We further detail the empirical specifications for each hypothesis in footnotes to tables 5-8. $d_{t}$ denotes time dummies, and $\epsilon_{i t}$ is the error term that consists of firm fixed effects, potentially time-variant unobserved heterogeneity, and an iid error term.

\subsection{Dependent variable - Tobin's $Q$}

Tobin’s Q is estimated with the determinants used in extant literature (Klapper and Love, 2004, Villalonga and Amit, 2006), in the following specification:

$$
\begin{aligned}
& Q_{i t}=\beta_{0}+\beta_{1} * \ln \left(\text { Sales }_{i t}\right)+\beta_{2} * \ln \left(\text { Debt }_{i t}\right)+\beta_{3} * \ln \left(\text { Investment }_{i t}\right)+\beta_{4} * \\
& \left(\frac{\text { dividend }}{\text { assets }}\right)_{i, t}+\beta_{5} X_{i t}+d_{t}+\epsilon_{i t} \quad \text { (2), }
\end{aligned}
$$

where $X_{i t}$ is a vector of explanatory variables that determine TD, and horizontal/vertical power variables. The dividend ratio, investment and debt (in natural logarithms) are used as determinants of Tobin's Q based on Villalonga and Amit (2006, Table 4). Debt drives investment opportunities by providing resources, while dividends impact Tobin's Q as they can play a role in limiting minority shareholder expropriation by removing corporate wealth

1970) used the level of investment. (Clark, et al., 1979) and (Bernanke, et al., 1988) used investment to sales ratios. Concern with stationarity issues has caused many recent authors to use the first difference of investment in an error correction framework (Driver and Moreton, 1991) - see a comparison of five different models using this specification in (Rapach and Wohar, 2007). Using the log of (gross) investment is an alternative to normalizing it by sales, so as to reduce the problems of skewness and heteroscedasticity. For these reasons, we believe the use of $i_{i t}$, as used in Driver et al. (2005) is a more reliable choice with our data. 
from blockholder control (Faccio, et al., 2001, Jensen, 1986). Sales (in natural logarithm) are used as a proxy for firm size (Durnev and Kim, 2005, Klapper and Love, 2004). As before, $d_{t}$ denotes time dummies, and $\epsilon_{i t}$ is the error term including firm fixed effects, potentially timevariant unobserved heterogeneity, and an iid error term.

\section{RESULTS}

To estimate the effects of network centrality and powerful owners for hypotheses $\mathrm{H} 2$ and $\mathrm{H} 4$ respectively, we utilize a cross-sectional model. Our ownership data reflect the year 2005, and we estimate the impact of these variables on the average values over the period of 2005-2010.

To estimate the moderating effects of the time-invariant ownership variables, we interact the TD variable with a set of mutually exclusive and collectively exhaustive dummies that represent the firms’ long-term positions in the ownership network or ownership structures. In our first set of moderating analyses assessing the owners' horizontal powers and their ability to access resources (H3), we interact TD with dummies representing high or low centrality in the projected one-mode network of firms. In the second set of moderating analyses assessing the owners' vertical powers and the associated agency costs (H5), we interact TD with dummies for the combinations of RSPP board membership and single controlling owner binary variables. This amounts to estimating the interaction between TD and the ownership variables, but because of high correlations between the ownership variables, and their cross-sectional and binary nature, we operationalize the interactions through their mutually exclusive combinations (cf. Leiponen, 2005). This allows us to best distinguish the implications on fixed investment and Tobin's Q of different organizational configurations.

Table 3 provides the number of observations and the number of firms for each mutually exclusive combination, their interactions with TD scores, including control 
variables and average values of investment as dependent variable and TD. When accounting for non-missing observations of these variables, the total number of observations by combination is broken down and sums up to 398, across years, for 99 firms in total, which matches the number of observations found in the fixed effects models.

\section{INSERT TABLE 3 ABOUT HERE}

In addition to fixed effects, we apply dynamic GMM (generalized method of moments) estimators (Arellano and Bover, 1995, Blundell and Bond, 1998), which incorporate the dynamic nature of the TD-ownership relationship and utilize instruments that control for time-variant unobserved heterogeneity and simultaneity (Wintoki, et al., 2012). The use of GMM is required if the lagged dependent variable introduces Nickell's bias (Nickell, 1981). We limit the number of instruments by using the 'collapse' function as in Roodman (2009), which creates one instrument for each variable and lag distance, rather than one for each time period, variable and lag distance. The collapse option significantly increases the power of the Hansen test of over-identification.

In our first set of estimations, reported in Table 4, we present cross-sectional evidence about the effects of the ownership network on investment and Tobin's Q. These should be interpreted as descriptive evidence. We find that investment levels are significantly positively correlated with corporate governance and ownership network centrality. We also find a weakly negative coefficient of state ownership. The coefficients of RSPP membership and single major shareholder are also negative but not statistically significant. We find that Tobin’s Q is significantly negatively correlated with corporate governance and not correlated with degree centrality which might indicate that undervalued firms (low Tobin’s Q) would benefit more from corporate governance than overvalued firms. Tobin’s Q is also significantly and positively correlated with foreign exchange binary variable, which indicates 
that firms listed abroad have higher valuations. These results are aligned with hypotheses 1 and 2 regarding the direct effects of TD and network positions with investment as the dependent variable, whereas hypothesis 4 regarding the negative effect of powerful controlling owners is not supported. The weak negative coefficient of state ownership suggests that state-owned firms have weaker performance incentives due to soft budget constraints, or that the state tends to exercise its power and expropriate value from stateowned firms.

Endogeneity can be a concern due to reverse causality between ownership structure and firm outcomes. However, ownership structures in East European economies are relatively stable over time (La Porta, et al., 1999), suggesting that the changes of the firm's fundamentals are not the main drivers of the ownership structure changes. Nevertheless, there may be other factors that confound the effect of ownership on investment and Tobin's Q. For example, new investment opportunities or technologies may both make ownership attractive and lead to a higher Tobin's Q, in which case the coefficients of ownership variables might be inflated. Therefore we suggest these results are descriptive.

INSERT TABLE 4 ABOUT HERE

Next, we test for the impact of horizontal power of controlling owners, as articulated in hypothesis 3. The results in Tables 5 and 6 suggest that ownership network connections significantly moderate the effects of transparency on investment and Tobin's Q. Here we estimate the effect of TD separately for highly-connected firms and poorly-connected firms, which sums to the entire sample, hence we do not need to report the direct effect of centrality variable on firm outcomes. TD scores are positive and statistically significant only for peripheral (poorly-connected) firms. 
In economic terms, every 1 percent increase of TD for peripheral firms would entail a 0.33 percent increase in investment (Table 5) and a larger and equally significant increase of 13.75 in Tobin's Q (Table 6) in the respective fixed effects models, and 1.04 percent increase in investment and a larger and equally significant increase of 14.40 percent in Tobin's Q in the respective GMM models. We thus obtain statistically and economically significant evidence that improvements in TD only matter for investments of peripheral firms. Central firms controlled by horizontally powerful owners may address the resource provision through their ownership network, whereas peripheral firms need to invest in corporate governance practices to access these resources. Our specification tests support the validity of our instruments for identification.

\section{INSERT TABLES 5 AND 6 ABOUT HERE}

Tables 7 and 8 examine hypothesis 5 regarding the principal-principal agency costs associated with vertically powerful owners. This was operationalized as the interaction of TD scores with four mutually exclusive combinations of a single controlling owner and RSPP board membership binary variables (as before, these coefficients include the "direct” effect of TD on firm investment and Tobin’s Q). We expected agency costs to be the highest for the combination $(1,1)$, where both a single controlling shareholder and RSPP membership are present.

INSERT TABLE 7 AND TABLE 8 ABOUT HERE

Results in Tables 7 and 8 suggest that the coefficient of TD is systematically positive and significant only for firms with more vertically powerful owners or severe agency hazards, i.e. $(1,1)$ combination. The $(0,0)$ combination (firms with multiple owners none of whom are RSPP board members) is associated with insignificant negative coefficient for TD. We 
interpret these coefficients as supporting evidence for the argument that TD matters more for firms that have greater power asymmetries resulting in principal-principal agency costs.

To acknowledge the state as another powerful owner, we replicated the model in Table 7 for the combination of state ownership and a single controlling owner. The results (reported in supplementary analyses, Table 2A) are aligned with those in Table 7. Firms with the state as the single controlling owner benefit from TD practices which supports greater investment or Tobin's Q. The effects are statistically significant in both fixed effects and GMM models. We thus obtain evidence that state ownership induces power asymmetries which the firm can counteract by adopting stricter TD practices. In sum, when central firms have the state as one of the controlling owners, state ownership appears to provide resources for investment and innovation if the state is not the only controlling owner, but if state is the single powerful owner, TD practices can mitigate the principal-principal agency issues that may arise. However, overall, the strongest effects of TD are observed for firms with a single non-state owner (Table 2A, Q regressions and the GMM investment regression). Taken together with the results in table $1 \mathrm{~A}$, we conclude that the effects on investment and Tobin's Q are overall most pronounced for private firms.

In summary, the estimation results support most of our hypotheses. Hypotheses 1, 2 and 4 concern the average effects of corporate governance, horizontal power of owners (ownership network centrality), and vertical power of owners, and are mostly supported by descriptive evidence from cross-sectional OLS regressions. We find that TD practices and horizontal power of owners significantly increase investment, whereas the average effect of the vertical power of owners is insignificant and that of state ownership is negative and weakly significant.

However, most interestingly, the effects of our key independent variables significantly interact with one another. Hypothesis 3 predicted that if the firm's central position in the 
ownership network primarily facilitates access to resources for the company, TD practices will be redundant for acquiring resources for such horizontally powerful owners. Indeed, we find that if firms cannot obtain resources through their owners' connections, they greatly benefit from improvements in TD practices, which are likely to enable them to increase internal efficiency and attract external investors. Hypothesis 5 suggested that excessive hierarchical (vertical) power that primarily cause agency costs will positively interact with TD in predicting firm outcomes such as investment and Tobin's Q. As mentioned above, we find that private firms with a single, vertically powerful owner significantly benefit from TD practices. Firms can increase their internal accountability through TD and thus credibly reduce their powerful owners’ opportunities to expropriate resources.

\subsection{Robustness checks and alternative explanations}

We carried out a number of tests for robustness and to evaluate alternative explanations. We first tested whether the unbalanced nature of the panel influences the results, and found that the data are sufficiently persistent. For example, if we select a sub-sample from the panel only including firms with three consecutive observations of TD score, the results are unchanged.

We analyzed the interactions of horizontal and vertical powers by testing for the effects of RSPP interacted with the measures of centrality. The results showed that TD is more important for peripheral firms with RSPP owners than for other types of firms. In other words, TD matters the most for peripheral firms that suffer from power asymmetries. Such firms are subject to both information and agency disadvantages.

Since TD scores might be endogenous, we tested our hypotheses with fixed effects to control for permanent firm characteristics (including ownership in our case) ${ }^{9}$ and used

\footnotetext{
${ }^{9}$ We also produced random effects with industry dummies (unreported) and results supported our hypotheses
} 
instrumental variables (GMM estimator) to control for time-variant unobserved effects. Although our instruments are deemed valid by our specification tests, we cannot be absolutely certain that TD scores and investments are not confounded. However, we are mainly interested in how different ownership network positions and ownership characteristics impact the importance of TD scores, when all other factors are held constant, and this comparative set up alleviates the identification challenge. Even though TD might be caused by firms' unobservable and time-varying needs to secure funding, it is unlikely that those factors affect TD only under some ownership network conditions and not others. In other words, either only firms with certain ownership arrangements benefit from TD (i.e. TD enables investments for these firms), or only firms with certain ownership structures are subject to unobserved factors that cause both TD and investment variations. We believe that the former is more likely than the latter.

To further explore the impact of financing constraints on investment, we tested whether they moderate our results on the effects of TD and the ownership network. Firms in emerging economies tend to finance their investments mainly with equity (Seifert and Gonenc, 2010). Transparency is important to firms planning to raise equity in the public market. We proxy financing constraints by a binary variable taking the value 0 for unconstrained firms, i.e., firms that did not raise additional common equity through a secondary issue (Angelopoulou and Gibson, 2009) and paid common or preferred dividends (Fazzari, et al., 1988) and 1 for constrained firms, i.e. firms that issued common equity through a secondary issue in a given year. We interact it with the TD variable. We find that unconstrained firms benefit somewhat more greatly from TD practices but the differences are not substantial (these results are reported in Table A3 in the appendices with supplementary analyses). 
We also considered whether the effect of the ownership network is related to improving access to finance. We found that unconstrained central firms benefit the most from higher TD. ${ }^{10}$ Analyzing the moderating effect of financial constraints on the interaction of vertically powerful owners (single major owner or RSPP member ${ }^{11}$ ) and TD reveals that TD effects are also most pronounced in unconstrained firms. Taken together, these analyses suggest that the effects of TD, ownership network and PPA are not driven by financial constraints.

We also estimated a two-step Heckman selection model (Heckman, 1979) by evaluating in the first step the probability that a firm has a TD score, and in the second step considering the level of TD score as an outcome variable (results are not reported but are available upon request). This modelling approach accounts for the possibility that firms with TD scores have certain characteristics that may also be linked with how much they score on TD. S\&P selects firms to score on TD practices according to firm’s size and liquidity; hence we found in the first step of Heckman that whether the firm had a score or not depended on firm's sales (proxy for size) and free float percentage (proxy for liquidity). While S\&P is in charge of scoring the firms on their TD practices, the TD level is determined by the decision of firms regarding how transparent they want to be, and consequently, by their ownership structures and financing needs. In the second step of Heckman selection model, gross cash flow (a proxy for internal financing) and investment were positively related to the level of TD score; while firm centrality and RSPP board membership were significantly and negatively related to TD, in other words central firms and firms controlled by powerful RSPP members were less likely to have higher TD scores. Certain variables were not significant in

\footnotetext{
${ }^{10}$ Empirically, we compare the coefficients of four mutually exclusive interactions: TD*constrained*central firms, TD*unconstrained*central firms, TD*constrained*peripheral firms and TD*unconstrained*peripheral firms. The results are robust in both fixed effects and GMM.

${ }^{11}$ We have the following mutually exclusive terms: TD*constrained*single_owner, TD*unconstrained*single_owner, TD*constrained*multiple_owners, TD*unconstrained*multiple_owners; then do the same interactions for RSPP owners
} 
determining the level of TD scores, conditional on the firm being selected by S\&P, such as the presence of independent board directors. These results further reinforce our argument that TD scores are causally related with investment and access to external financing.

Because of data limitations and costs of collection, we were not able to collect a panel of ownership variables. However, changes in a firm’s ownership network position require time and substantial resources, and it seems reasonable to assume that firms would not be able to do that in order to simultaneously influence both investment and TD score. Indeed, our data collected for 2005 and 2009 suggest that ownership patterns are very stable and only rarely change: 79 percent of controlling owners of 2005 were still controlling the same companies in 2009 and only 25 percent of controlling owners of 2005 increased the number of firms they control in 2009.

Further, there may be agency problems arising from pyramidal structures. Firms at the bottom of a pyramid are likely to suffer more from expropriation by the controlling shareholder than firms at the top. Due to unavailability of TD scores for each subsidiary, we were unable to test for these agency problems. However, we assessed whether conglomerate structures influence our results for hypothesis 2 . We found that peripheral firms benefit from TD practices the most strongly if they are a part of a conglomerate. In this case, TD practices may alleviate both resource access and expropriation issues of conglomerates.

Finally, we separately accounted for the effect of centrality on private firms, to eliminate the effect of state connections. We constructed three interactions: central and private firms, peripheral and private firms, central and state-owned firms (there are no peripheral and state-owned firms in the sample). The results (reported in supplementary analysis, Table 1A) indicated that peripheral and private firms still significantly benefit from TD to improve their investments and Tobin's Q. Taking into account that while Russia is 
formally a federal country, it remains highly centralized in its administration, we identified a firm as state-owned regardless of what level of the government it belonged to ${ }^{12}$.

\section{CONCLUSION, IMPLICATIONS, AND FURTHER RESEARCH}

The unique oligarchic ownership network structures in Russia may be filling the institutional vacuum left by the collapsed communist economy, ensuring access to the requisite resources for improving assets' productivity and financial outcomes. However, the power of oligarchs over the companies within their control also creates opportunities for tremendous private gains, often at the expense of minority shareholders and potentially to the detriment of the overall economy. Furthermore, governments in emerging markets tend to exercise control over the economy through involvement in the governance of firms in "strategic" industries and by providing political support and preferential treatment. These privately or politically motivated interventions by controlling owners are likely to affect firm outcomes.

This paper examines how the power resulting from ownership network positions or specific ownership attributes may directly impact firm outcomes and interact with corporate governance practices. Corporate governance practices related to transparency and information disclosure (TD) were found to substitute for (negatively interact with) central network positions of horizontally powerful owners. In contrast, these governance practices were found to complement (positively interact with) ownership structures that generated hierarchical power asymmetries and agency conflicts.

\footnotetext{
${ }^{12}$ It is more likely that for the large publicly listed state-owned firms of our sample, the ultimate controlling entity is at the highest federal level. Let's consider two state-owned companies, the largest oil and gas producer Gazprom and the national telecom operator Rostelecom. In 2006, the Russian government controlled 50.23 percent of Gazprom shares through Rosimushchestvo, i.e. Federal Agency for Federal Property Management (38.373\%), Rosneftegaz (10.74\%), and Rosgazifikatsiya (0.889\%). Rostelecom is $45.04 \%$ owned by the state (the controlling shareholder) represented by Rosimushchestvo (as in Gazprom), with further 3.96\% controlled by Vnesheconombank, itself also owned by a state, 38.98\% is free float, and the remaining $12.01 \%$ owned by Mobitel, a subsidiary of Rostelecom . Hence, on the ownership level ties, these two companies are very similar as the state's largest stake is held through Rosimushchestvo, a federal-level organization.
} 
There are few studies that combine analysis of ownership characteristics and organizational transparency. We viewed different aspects of ownership and resulting power relationships from the social network perspective and the principal-principal agency perspective and examined how ownership arrangements interact with governance practices related to TD. Our results highlight that it is important for scholars to understand the different sources of owners’ power. Ownership connections to other controlling owners lead to accumulation of horizontal power through network centrality that generates trust and yields access to valuable resources. In contrast, connections through the Russian Union of Industrialists and Entrepreneurs or the state or the absence of multiple controlling shareholders may lead to increased vertical or hierarchical power of controlling shareholders over minority shareholders, and ultimately to expropriation hazards. Each type of power has different impact on firm behavior: horizontal power negatively moderates the relationship between TD and investment or value in terms of Tobin's Q, while vertical power positively moderates this relationship.

Our study has implications for managers and owners of firms operating in Russia or other emerging economies. On the one hand, managers may be able to counteract controlling owners' tendencies to use the firm as a vehicle to promote their private interests by strengthening corporate governance practices. Well-governed firms perform better, particularly if they have poorly-connected or vertically powerful owners. On the other hand, owners can enhance the value of their companies by developing and maintaining ties with horizontally powerful (well-connected) oligarchs and thus obtaining valuable information about or funding for investment opportunities.

This research also has implications for policymakers and investors choosing in which firms to invest. Returns to minority shareholders are likely to depend not only on internal management practices but also on the actions of the major shareholders, and minority 
investors will want to pay attention to the associated risks of expropriation. Therefore, investors may want to select better-networked and more transparent firms that are likely to generate more long-term growth. Whereas policymakers may have little control over the concentration of ownership of non-state-owned firms, they should enhance transparency about the ultimate owners and ownership stakes of large companies. The availability of this information would likely counterbalance the tendency of single controlling oligarchs to exercise their power to their own advantage, as the stock market would reduce incentives to tunnel out resources.

While in the empirical analyses we control for state ownership and also separately test for the moderating effects of state ownership on the impact of corporate governance, we acknowledge that there are multiple forces at work that influence these relationships which merit an in-depth analysis in future research. The state can provide firms with resources, such as information and finance (Coricelli and Djankov, 2001, Zhu, 2012) and favorable regulatory treatment (Peng and Luo, 2000), but it is also powerful enough to expropriate resources from firms, for example, by requiring inefficient pricing or supply arrangements with other state-owned enterprises. The implications of different types of state ownership for performance and corporate governance are therefore not straightforward. It is an empirical question regarding which of the aforementioned effects dominate in the research context (Grosman, et al., 2016, Lazzarini, et al., 2015).

Future research could also further explore the effect of financing constraints on different types of power. For example, are the impacts of horizontal and vertical power due to the fact that these power measures are related to financial constraints? That is, is it true that, e.g., horizontally powerful firms are less financially constrained, and this is responsible for the interaction effect of horizontal power and TD (because TD matters more for financially 
unconstrained firms). Similarly, the impacts of financial constraints on vertical power could be further explored.

Another natural extension to this study would be to devote more attention to the way ownership networks impact the board composition of Russian firms, e.g. by studying whether CEOs or shareholders from these networks are more likely to sit on one another's boards (board interlocks) and how the ownership network measures would moderate the boardperformance relationship. It would also be important to further explore the moderation effects of networks by examining the impact of network connectivity on the adoption of more stringent practices by the focal firm through contagion. It is possible that firms learn about corporate governance practices through their network connections. Finally, investigating the strategic effects of ownership networks in other emerging or developed economies would be valuable to assess the generalizability of these results. 


\section{REFERENCES}

Aggarwal, Rajesh K, Meschke, Felix, Wang, Tracy Yue, 2012. Corporate political donations: investment or agency? Business and Politics 14.

Ahmadjian, Christina, Oxley, Joanne, 2006. Using hostages to support exchange: Dependence balancing and partial equity stakes in Japanese automotive supply relationships. Journal of Law, Economics, and Organization 22, 213-233.

Ahuja, Gautam, 2000. Collaboration networks, structural holes, and innovation: A longitudinal study. Administrative Science Quarterly 45, 425-455.

Aidis, Ruta, Estrin, Saul, Mickiewicz, Tomasz, 2008. Institutions and entrepreneurship development in Russia: A comparative perspective. Journal of Business Venturing 23, 656-672.

Aksu, Mine, Kosedag, Arman, 2006. Transparency and disclosure scores and their determinants in the Istanbul Stock Exchange. Corporate Governance: An International Review 14, 277-296.

Almeida, Heitor V, Wolfenzon, Daniel, 2006. A theory of pyramidal ownership and family business groups. The Journal of Finance 61, 2637-2680.

Alon, Anna, 2013. Complexity and dual institutionality: The case of IFRS adoption in Russia. Corporate Governance: An International Review 21, 42-57.

Aminadav, Gur, Papaioannou, Elias, 2016. Corporate control around the world. National Bureau of Economic Research.

Angelopoulou, Eleni, Gibson, Heather D, 2009. The balance sheet channel of monetary policy transmission: evidence from the United Kingdom. Economica 76, 675-703.

Arellano, Manuel, Bover, Olympia, 1995. Another look at the instrumental variable estimation of error-components models. Journal of Econometrics 68, 29-51.

Astley, W Graham, Sachdeva, Paramjit S, 1984. Structural sources of intraorganizational power: A theoretical synthesis. Academy of Management Review 9, 104-113.

Bean, Charles R, 1981. An econometric model of manufacturing investment in the UK. The Economic Journal 91, 106-121.

Becker, Bettina, Hall, Stephen G, 2009. Foreign direct investment in R\&D and exchange rate uncertainty. Open Economies Review 20, 207-223.

Beekes, Wendy, Brown, Philip, 2006. Do better - governed Australian firms make more informative disclosures? Journal of Business Finance \& Accounting 33, 422-450.

Bellavitis, C., Filatotchev, I., Souitaris, V. , 2017. The impact of investment networks on venture capital firm performance: A contingency framework. British Journal of Management 28, 102119.

Bennedsen, Morten, Wolfenzon, Daniel, 2000. The balance of power in closely held corporations. Journal of Financial Economics 58, 113-139.

Bernanke, Ben, Bohn, Henning, Reiss, Peter C, 1988. Alternative non-nested specification tests of time-series investment models. Journal of Econometrics 37, 293-326.

Black, Bernard, Love, Inessa, Rachinsky, Andrei, 2006. Corporate governance indices and firms' market values: Time series evidence from Russia. Emerging Markets Review 7, 361-379.

Blau, Peter Michael, Schoenherr, Richard A, 1971. The structure of organisations. Basic Books New York.

Blundell, Richard, Bond, Stephen, 1998. Initial conditions and moment restrictions in dynamic panel data models. Journal of Econometrics 87, 115-143.

Bonacich, Phillip, 1987. Power and centrality: A family of measures. American Journal of Sociology 92, 1170-1182.

Bond, Stephen, Elston, Julie Ann, Mairesse, Jacques, Mulkay, Benoît, 2003. Financial factors and investment in Belgium, France, Germany, and the United Kingdom: A comparison using company panel data. Review of Economics and Statistics 85, 153-165.

Borgatti, Stephen P, Everett, Martin G, Freeman, Linton C, 2002. Ucinet for Windows: Software for social network analysis. Analytic Technologies, Nicholasville, KY.

Braguinsky, Serguey, 2009. Postcommunist oligarchs in Russia: Quantitative analysis. Journal of Law and Economics 52, 307-349. 
Braguinsky, Serguey, Myerson, Roger, 2007. A macroeconomic model of Russian transition. Economics of Transition 15, 77-107.

Burkart, Mike, Panunzi, Fausto, Shleifer, Andrei, 2003. Family firms. The Journal of Finance 58, 2167-2201.

Campos, Nauro F, Giovannoni, Francesco, 2006. The Determinants of Asset Stripping: Theory and Evidence from the Transition Economies. Journal of Law and Economics 49, 681-706.

Chernykh, Lucy, 2008. Ultimate ownership and control in Russia. Journal of Financial Economics 88, 169-192.

Cimoli, Mario, Dosi, Giovanni, Stiglitz, Joseph E, 2009. Industrial policy and development: The political economy of capabilities accumulation. Oxford University Press, Oxford.

Clark, Colin W, Clarke, Frank H, Munro, Gordon R, 1979. The optimal exploitation of renewable resource stocks: problems of irreversible investment. Econometrica: Journal of the Econometric Society, 25-47.

Cook, Karen S, 1977. Exchange and power in networks of interorganizational relations. The Sociological Quarterly 18, 62-82.

Cooper, Michael J, Gulen, Huseyin, Ovtchinnikov, Alexei V, 2010. Corporate political contributions and stock returns. The Journal of Finance 65, 687-724.

Coricelli, Fabrizio, Djankov, Simeon, 2001. Hardened budgets and enterprise restructuring: theory and an application to Romania. Journal of Comparative Economics 29, 749-763.

Dahl, Robert A, 1957. The concept of power. Behavioral Science 2, 201-215.

De Long, J Bradford, Summers, Lawrence H, 1991. Equipment investment and economic growth. Quarterly Journal of Economics 106, 445-502.

Driver, Ciaran, Moreton, David, 1991. The influence of uncertainty on UK manufacturing investment. The Economic Journal 101, 1452-1459.

Driver, Ciaran, Temple, Paul, Urga, Giovanni, 2005. Profitability, capacity, and uncertainty: a model of UK manufacturing investment. Oxford Economic Papers 57, 120-141.

Durnev, Art, Kim, E. Han, 2005. To steal or not to steal: Firm attributes, legal environment, and valuation. The Journal of Finance 60, 1461-1493.

Dyck, Alexander, Zingales, Luigi, 2004. Private benefits of control: An international comparison. The Journal of Finance 59, 537-600.

Dzarasov, Ruslan, 2010. Eichnerian megacorp and investment behaviour of Russian corporations. Cambridge Journal of Economics 35, 199-217.

Edling, Christofer, Hobdari, Bersant, Randøy, Trond, Stafsudd, Anna, Thomsen, Steen, 2012. Testing the "old boys' network": diversity and board interlocks in Scandinavia. In: Kogut, Bruce, (Ed., The Small Worlds of Corporate Governance. MIT Press, Cambridge, MA, pp. 183-202.

Emerson, Richard M, 1962. Power-dependence relations. American Sociological Review 27, 31-41.

Enikolopov, Ruben, Petrova, Maria, Stepanov, Sergey, 2014. Firm value in crisis: Effects of firmlevel transparency and country-level institutions. Journal of Banking \& Finance 46, 72-84.

Enikolopov, Ruben, Stepanov, Sergey, 2013. Corporate governance in Russia. In: Alexeev, Michael, Weber, Shlomo, (Eds.), The Oxford handbook of the Russian economy. Oxford University Press, Oxford, pp. 221-245.

Estrin, Saul, Poukliakova, Svetlana, Shapiro, Daniel, 2009. The performance effects of business groups in Russia. Journal of Management Studies 46, 393-420.

Faccio, Mara, 2006. Politically connected firms. The American Economic Review 96, 369-386.

Faccio, Mara, Lang, Larry HP, Young, Leslie, 2001. Dividends and expropriation. American Economic Review 91, 54-78.

Fazzari, Steven, Hubbard, R Glenn, Petersen, Bruce C, 1988. Financing constraints and corporate investment. Brookings Papers on Economic Activity 1, 141-206.

Filatotchev, Igor, Wright, Mike, 2011. Agency perspectives on corporate governance of multinational enterprises. Journal of Management Studies 48, 471-486.

Filatotchev, Igor, Wright, Mike, Bleaney, Michael, 1999. Privatization, insider control and managerial entrenchment in Russia. Economics of Transition 7, 481-504.

Franks, Julian R, Mayer, Colin, 2017. Evolution of Ownership and Control Around the World: The Changing Face of Capitalism. 
Freeman, Linton C, Roeder, Douglas, Mulholland, Robert R, 1979. Centrality in social networks: II. Experimental results. Social Networks 2, 119-141.

Frye, Timothy, 2002. Capture or exchange? Business lobbying in Russia. Europe-Asia Studies 54, 1017-1036.

Frye, Timothy M, Iwasaki, Ichiro, 2011. Government directors and business-state relations in Russia. European Journal of Political Economy 27, 642-658.

Frynas, Jędrzej George, Mellahi, Kamel, Pigman, Geoffrey Allen, 2006. First mover advantages in international business and firm - specific political resources. Strategic Management Journal 27, 321-345.

Granovetter, Mark, 1974. Getting a job: A study of contacts and careers. Harvard University, Cambridge, MA.

Granovetter, Mark, 1985. Economic action and social structure: The problem of embeddedness. American Journal of Sociology 91, 481-510.

Grosman, Anna, Okhmatovskiy, Ilya, Wright, Mike, 2016. State Control and Corporate Governance in Transition Economies: 25 Years on from 1989. Corporate Governance: An International Review 24, 200-221.

Guriev, Sergei, Rachinsky, Andrei, 2005. The role of oligarchs in Russian capitalism. The Journal of Economic Perspectives 19, 131-150.

Hanson, Philip, Teague, Elizabeth, 2005. Big business and the state in Russia. Europe-Asia Studies 57, 657-680.

Heckman, James J, 1979. Sample selection bias as a specification error. Econometrica, 153-161.

Higley, John, Hoffmann-Lange, Ursula, Kadushin, Charles, Moore, Gwen, 1991. Elite integration in stable democracies: A reconsideration. European Sociological Review 7, 35-53.

Hillman, Amy J, 2005. Politicians on the board of directors: Do connections affect the bottom line? Journal of Management 31, 464-481.

Hoffman, David, 2011. The oligarchs: Wealth and power in the new Russia. PublicAffairs, New York.

Holm, Desiree Blankenburg, Eriksson, Kent, Johanson, Jan, 1999. Creating value through mutual commitment to business network relationships. Strategic Management Journal 20, 467-486.

Hope, Ole - Kristian, 2003. Firm - level disclosures and the relative roles of culture and legal origin. Journal of International Financial Management \& Accounting 14, 218-248.

Inoue, Carlos FKV, Lazzarini, Sergio G, Musacchio, Aldo, 2013. Leviathan as a Minority Shareholder: Firm-Level Implications of State Equity Purchases. Academy of Management Journal 56, 1775-1801.

Jensen, Michael C, 1986. Agency cost of free cash flow, corporate finance, and takeovers. The American Economic Review 76, 323-329.

Jorgenson, Dale W, Hunter, Jerald, Nadiri, M Ishag, 1970. A comparison of alternative econometric models of quarterly investment behavior. Econometrica (pre-1986) 38, 187.

Kadushin, Charles, 1995. Friendship among the French financial elite. American Sociological Review, 202-221.

Khanna, Tarun, Palepu, Krishna, 2000. Is group affiliation profitable in emerging markets? An analysis of diversified Indian business groups. The Journal of Finance 55, 867-891.

Klapper, Leora F, Love, Inessa, 2004. Corporate governance, investor protection, and performance in emerging markets. Journal of Corporate Finance 10, 703-728.

La Porta, Rafael, Lopez - de - Silanes, Florencio, Shleifer, Andrei, 1999. Corporate ownership around the world. The Journal of Finance 54, 471-517.

Laeven, Luc, Levine, Ross, 2008. Complex ownership structures and corporate valuations. Review of Financial Studies 21, 579-604.

Lazareva, Olga, Rachinsky, Andrei, Stepanov, Sergey, 2009. A survey of corporate governance in Russia. In: McGee, Robert W., (Ed., Corporate Governance in Transition Economies. Springer, New York, pp. 315-349.

Lazzarini, Sergio G, Musacchio, Aldo, Bandeira-de-Mello, Rodrigo, Marcon, Rosilene, 2015. What do state-owned development banks do? Evidence from BNDES, 2002-09. World Development 66, 237-253. 
Ledeneva, Alena V, 1998. Russia's economy of favours: Blat, networking and informal exchange. Cambridge University Press, Cambridge.

Leiponen, Aija, 2005. Skills and innovation. International Journal of Industrial Organization 23, 303323.

Leiponen, Aija Elina, 2008. Competing through cooperation: The organization of standard setting in wireless telecommunications. Management Science 54, 1904-1919.

Lins, Karl V, 2003. Equity ownership and firm value in emerging markets. Journal of Financial and Quantitative Analysis 38, 159-184.

Liu, Mingzhi, Magnan, Michel, 2011. Self - dealing regulations, ownership wedge, and corporate valuation: International evidence. Corporate Governance: An International Review 19, 99115.

Luo, Xiaowei, Chung, Chi-Nien, 2005. Keeping it all in the family: The role of particularistic relationships in business group performance during institutional transition. Administrative Science Quarterly 50, 404-439.

Mairesse, Jacques, Hall, Bronwyn H, Mulkay, Benoit, 1999. Firm-level investment in France and the United States: An exploration of what we have learned in twenty years. National Bureau of Economic Research, Cambridge, MA.

Masulis, Ronald W, Pham, Peter Kien, Zein, Jason, 2011. Family business groups around the world: Financing advantages, control motivations, and organizational choices. The Review of Financial Studies 24, 3556-3600.

Melkumov, Dmitri, 2009. Institutional background as a determinant of boards of directors' internal and external roles: The case of Russia. Journal of World Business 44, 94-103.

Nickell, Stephen, 1981. Biases in dynamic models with fixed effects. Econometrica, 1417-1426.

OECD, 2004. OECD Principles of Corporate Governance. OECD, Paris.

Okhmatovskiy, Ilya, 2010. Performance implications of ties to the government and SOEs: A political embeddedness perspective. Journal of Management Studies 47, 1020-1047.

Pappe, Ya, Antonenko, N, 2011. On new configurations of owners of Russian big business. Voprosy Ekonomiki, 123.

Patel, Sandeep A, Balic, Amra, Bwakira, Liliane, 2002. Measuring transparency and disclosure at firm-level in emerging markets. Emerging Markets Review 3, 325-337.

Peabody, Robert L, 1962. Perceptions of organizational authority: A comparative analysis. Administrative Science Quarterly 6, 463-482.

Peng, Mike W, Luo, Yadong, 2000. Managerial ties and firm performance in a transition economy: The nature of a micro-macro link. Academy of Management Journal 43, 486-501.

Phelps, Corey C, 2010. A longitudinal study of the influence of alliance network structure and composition on firm exploratory innovation. Academy of Management Journal 53, 890-913.

Pisano, Gary P, 1989. Using equity participation to support exchange: Evidence from the biotechnology industry. Journal of Law, Economics, \& Organization 5, 109-126.

Portes, Alejandro, Sensenbrenner, Julia, 1993. Embeddedness and immigration: Notes on the social determinants of economic action. American Journal of Sociology 98, 1320-1350.

Puffer, Sheila M, McCarthy, Daniel J, 2011. Two decades of Russian business and management research: An institutional theory perspective. The Academy of Management Perspectives 25, 21-36.

Rapach, David E, Wohar, Mark E, 2007. Forecasting the recent behavior of US business fixed investment spending: an analysis of competing models. Journal of Forecasting 26, 33-51.

Roodman, David, 2009. How to do xtabond2: An introduction to difference and system GMM in Stata. Stata Journal 9, 86.

Seifert, Bruce, Gonenc, Halit, 2010. Pecking order behavior in emerging markets. Journal of International Financial Management \& Accounting 21, 1-31.

Sun, Pei, Hu, Helen W, Hillman, Amy J, 2016. The dark side of board political capital: Enabling blockholder rent appropriation. Academy of Management Journal 59, 1801-1822.

Sun, Pei, Mellahi, Kamel, Thun, Eric, 2010. The dynamic value of MNE political embeddedness: The case of the Chinese automobile industry. Journal of International Business Studies 41, 11611182. 
Szakonyi, David, 2016. Businesspeople in Elected Office: Identifying Private Benefits from FirmLevel Returns.

Villalonga, Belen, Amit, Raphael, 2006. How do family ownership, control and management affect firm value? Journal of Financial Economics 80, 385-417.

Vries, Manfred FR, Florent - Treacy, Elizabeth, 2003. Roustam Tariko (A): Russian Entrepreneur. Entrepreneurship Theory and Practice 27, 299-313.

Wellman, Barry, 1983. Network analysis: Some basic principles. Sociological Theory 1, 155-200.

Westphal, James D, Khanna, Poonam, 2003. Keeping directors in line: Social distancing as a control mechanism in the corporate elite. Administrative Science Quarterly 48, 361-398.

Williamson, Oliver E, 1983. Credible commitments: Using hostages to support exchange. The American Economic Review, 519-540.

Wintoki, M Babajide, Linck, James S, Netter, Jeffry M, 2012. Endogeneity and the dynamics of internal corporate governance. Journal of Financial Economics 105, 581-606.

Wright, Mike, Filatotchev, Igor, Hoskisson, Robert E, Peng, Mike W, 2005. Strategy research in emerging economies: Challenging the conventional wisdom. Journal of Management Studies 42, 1-33.

Zhu, Xiaodong, 2012. Understanding China's growth: past, present, and future. Journal of Economic Perspectives 26, 103-124.

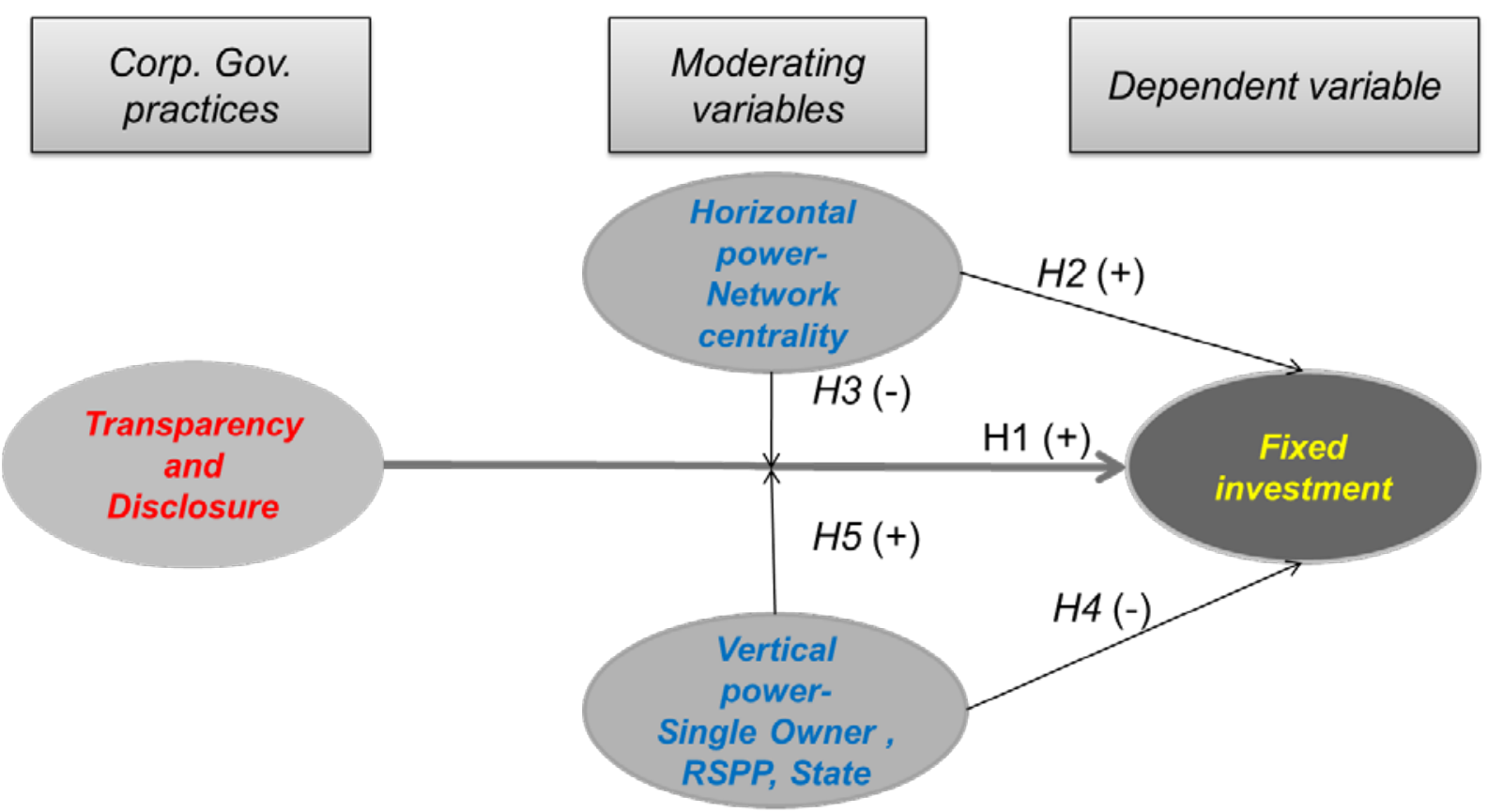

Figure 1. Transparency and ownership networks - concepts and operationalization 


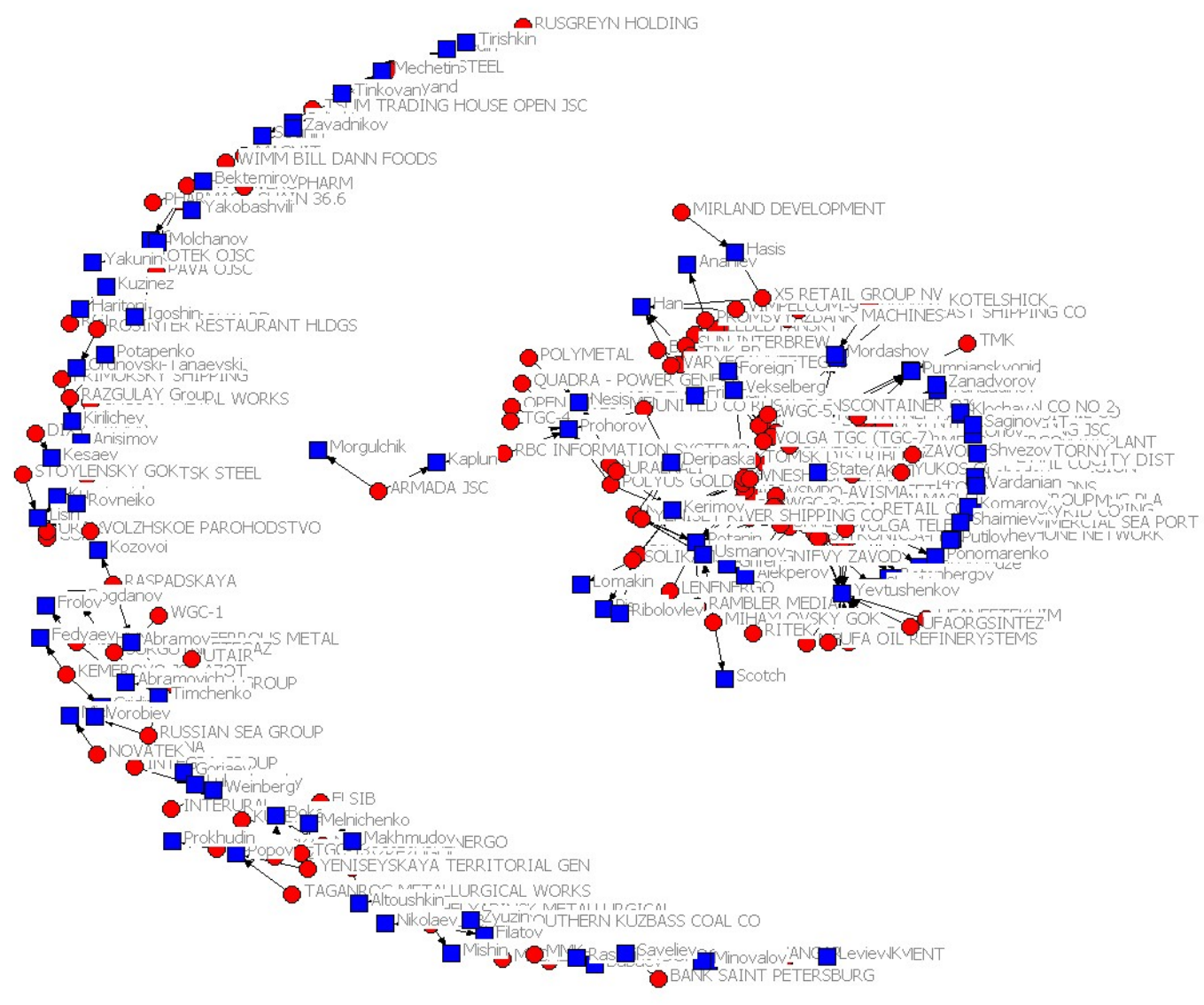

Figure 2. 2-mode firm-owner network

Note: Owners are represented by (blue) squares, firms by (red) circles

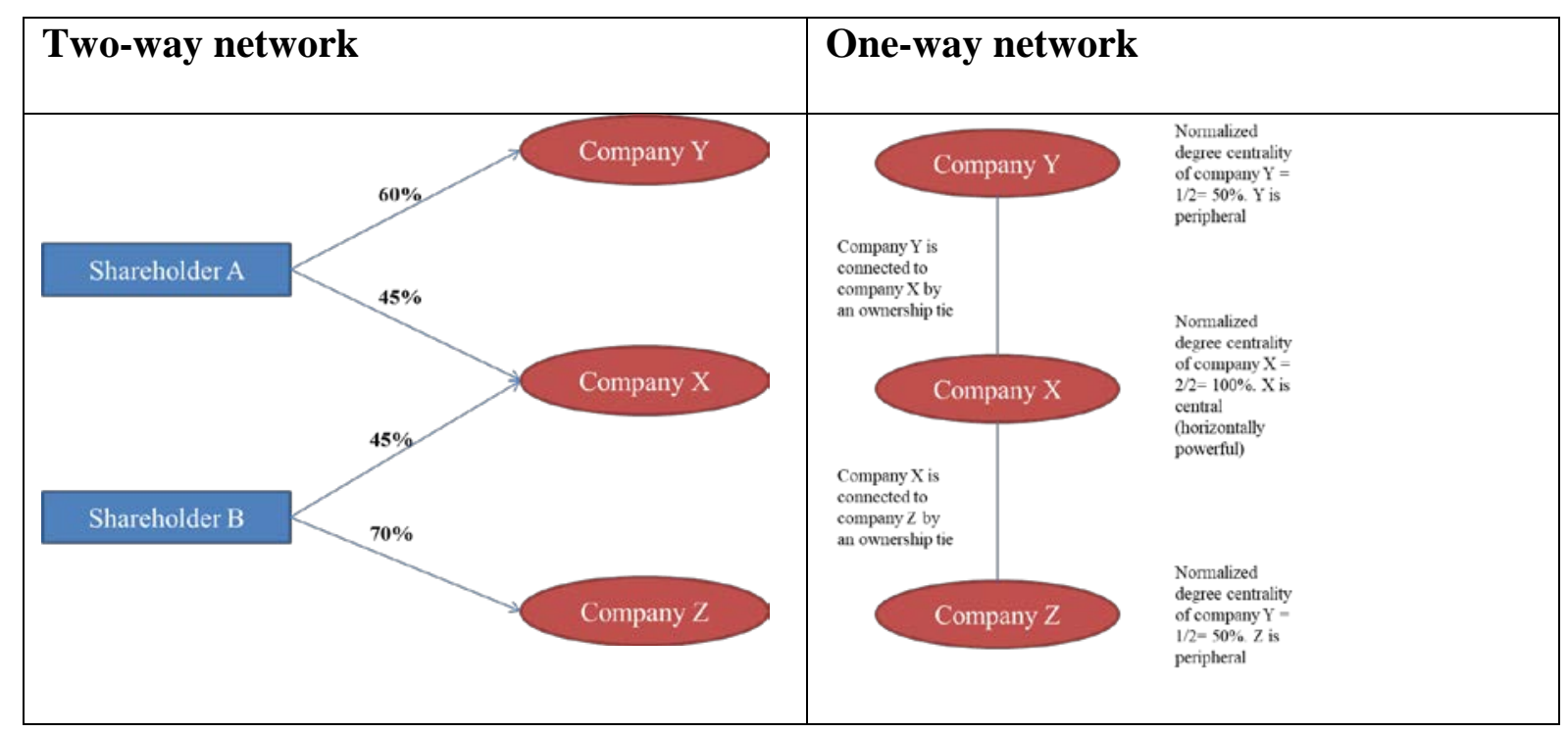

Figure 3. An illustrative example for the original two-mode network and a transformed

one-mode network 
Table 1. Descriptive statistics

\begin{tabular}{lccccc}
\hline Variable & Mean & Median & Stand. Dev. & Min & Max \\
\hline Capital investment, EURm & 774 & 182 & 2,102 & 0.5 & 20,608 \\
Sales, EURm & 5,345 & 1,344 & 11,289 & 20.4 & 86,214 \\
Gross cash flow, EURm & 1,211 & 214 & 3,019 & $-1,163$ & 24,519 \\
New equity, EURm & 168 & 0 & 628 & 0 & 6,436 \\
New debt, EURm & 314 & 6 & 934 & 0 & 7,687 \\
EBIT margin, \% & $16 \%$ & $16 \%$ & $29 \%$ & neg & $62 \%$ \\
Tobin's Q & 2.75 & 0.79 & 20 & 0.02 & 236 \\
Dividends to assets, \% & $2 \%$ & $1 \%$ & $4 \%$ & $0 \%$ & $31 \%$ \\
Financial constraints dummy & 0.37 & 0 & 0.48 & 0 & 1 \\
TD score, \% & $55 \%$ & $57 \%$ & $15 \%$ & $11 \%$ & $85 \%$ \\
Degree centrality, \% & $22 \%$ & $10 \%$ & $21 \%$ & $0 \%$ & $52 \%$ \\
Number of owners & 1.48 & 1 & 0.80 & 0 & 5 \\
Single owner dummy & 0.61 & 1 & 0.49 & 0 & 1 \\
RSPP membership dummy & 0.51 & 1 & 0.50 & 0 & 1 \\
State owner dummy & 0.54 & 1 & 0.49 & 0 & 1 \\
Foreign exchange dummy & 0.39 & 0 & 0.49 & 0 & 1
\end{tabular}

Notes: These variables are used in estimates, and are either reported in tables or robustness checks 
Table 2. Spearman's rank correlations

\begin{tabular}{|c|c|c|c|c|c|c|c|c|c|c|c|c|c|c|c|}
\hline & 1 & 2 & 3 & 4 & 5 & 6 & 7 & 8 & 9 & 10 & 11 & 12 & 13 & 14 & 15 \\
\hline 1. Investment & 1.000 & & & & & & & & & & & & & & \\
\hline \multirow[t]{2}{*}{ 2. Sales } & 0.849 & 1.000 & & & & & & & & & & & & & \\
\hline & 0.000 & & & & & & & & & & & & & & \\
\hline \multirow[t]{2}{*}{ 3. Gross cash-flow } & 0.829 & 0.819 & 1.000 & & & & & & & & & & & & \\
\hline & 0.000 & 0.000 & & & & & & & & & & & & & \\
\hline \multirow[t]{2}{*}{ 4. New equity } & -0.127 & -0.120 & -0.218 & 1.000 & & & & & & & & & & & \\
\hline & 0.053 & 0.068 & 0.001 & & & & & & & & & & & & \\
\hline \multirow[t]{2}{*}{ 5. New debt } & 0.407 & 0.348 & 0.254 & -0.050 & 1.000 & & & & & & & & & & \\
\hline & 0.000 & 0.000 & 0.000 & 0.445 & & & & & & & & & & & \\
\hline \multirow[t]{2}{*}{ 6. EBIT margin } & 0.453 & 0.320 & 0.627 & -0.199 & 0.086 & 1.000 & & & & & & & & & \\
\hline & 0.000 & 0.000 & 0.000 & 0.002 & 0.189 & & & & & & & & & & \\
\hline \multirow[t]{2}{*}{ 7. Tobin's Q } & 0.020 & -0.021 & 0.059 & -0.045 & -0.124 & 0.186 & 1.000 & & & & & & & & \\
\hline & 0.761 & 0.755 & 0.368 & 0.496 & 0.060 & 0.004 & & & & & & & & & \\
\hline \multirow[t]{2}{*}{ 8. Dividends ratio } & 0.465 & 0.421 & 0.575 & -0.274 & 0.161 & 0.528 & 0.241 & 1.000 & & & & & & & \\
\hline & 0.000 & 0.000 & 0.000 & 0.000 & 0.014 & 0.000 & 0.000 & & & & & & & & \\
\hline \multirow[t]{2}{*}{$\begin{array}{l}\text { 9. Financial } \\
\text { constraints }\end{array}$} & -0.187 & -0.183 & -0.280 & 0.971 & -0.069 & -0.214 & -0.054 & -0.313 & 1.000 & & & & & & \\
\hline & 0.004 & 0.005 & 0.000 & 0.000 & 0.295 & 0.001 & 0.411 & 0.000 & & & & & & & \\
\hline \multirow[t]{2}{*}{ 10. TD score } & 0.509 & 0.380 & 0.479 & -0.085 & 0.263 & 0.319 & 0.034 & 0.341 & -0.115 & 1.000 & & & & & \\
\hline & 0.000 & 0.000 & 0.000 & 0.196 & 0.000 & 0.000 & 0.605 & 0.000 & 0.080 & & & & & & \\
\hline \multirow[t]{2}{*}{ 11. Degree centrality } & 0.120 & 0.070 & 0.113 & -0.073 & -0.057 & -0.024 & -0.244 & -0.010 & -0.080 & -0.110 & 1.000 & & & & \\
\hline & 0.068 & 0.288 & 0.086 & 0.270 & 0.383 & 0.711 & 0.000 & 0.875 & 0.222 & 0.095 & & & & & \\
\hline \multirow[t]{2}{*}{ 12. Number of owners } & 0.185 & 0.245 & 0.211 & -0.050 & 0.121 & 0.154 & 0.053 & 0.009 & -0.060 & -0.183 & 0.254 & 1.000 & & & \\
\hline & 0.005 & 0.000 & 0.001 & 0.450 & 0.066 & 0.019 & 0.423 & 0.889 & 0.365 & 0.005 & 0.000 & & & & \\
\hline 13. Single owner & $\begin{array}{r}-0.186 \\
0.004\end{array}$ & $\begin{array}{r}-0.256 \\
0.000\end{array}$ & $\begin{array}{r}-0.207 \\
0.002\end{array}$ & $\begin{array}{l}0.035 \\
0.591\end{array}$ & $\begin{array}{r}-0.146 \\
0.026\end{array}$ & $\begin{array}{r}-0.133 \\
0.042\end{array}$ & $\begin{array}{r}-0.022 \\
0.742\end{array}$ & $\begin{array}{l}0.014 \\
0.836\end{array}$ & $\begin{array}{l}0.042 \\
0.528\end{array}$ & $\begin{array}{l}0.175 \\
0.008\end{array}$ & $\begin{array}{r}-0.226 \\
0.001\end{array}$ & $\begin{array}{r}-0.979 \\
0.000\end{array}$ & 1.000 & & \\
\hline 14. RSPP membership & $\begin{array}{l}0.375 \\
0.000\end{array}$ & $\begin{array}{l}0.444 \\
0.000\end{array}$ & $\begin{array}{l}0.345 \\
0.000\end{array}$ & $\begin{array}{l}0.021 \\
0.756\end{array}$ & $\begin{array}{l}0.219 \\
0.001\end{array}$ & $\begin{array}{l}0.169 \\
0.010\end{array}$ & $\begin{array}{r}-0.034 \\
0.604\end{array}$ & $\begin{array}{l}0.077 \\
0.242\end{array}$ & $\begin{array}{r}-0.007 \\
0.920\end{array}$ & $\begin{array}{l}0.116 \\
0.077\end{array}$ & $\begin{array}{r}-0.090 \\
0.173\end{array}$ & $\begin{array}{l}0.545 \\
0.000\end{array}$ & $\begin{array}{r}-0.545 \\
0.000\end{array}$ & 1.000 & \\
\hline 15. State owner & $\begin{array}{l}0.039 \\
0.553\end{array}$ & $\begin{array}{l}0.047 \\
0.478\end{array}$ & $\begin{array}{r}-0.004 \\
0.958\end{array}$ & $\begin{array}{r}-0.032 \\
0.625\end{array}$ & $\begin{array}{l}0.010 \\
0.876\end{array}$ & $\begin{array}{r}-0.224 \\
0.001\end{array}$ & $\begin{array}{r}-0.308 \\
0.000\end{array}$ & $\begin{array}{r}-0.107 \\
0.104\end{array}$ & $\begin{array}{r}-0.043 \\
0.513\end{array}$ & $\begin{array}{r}-0.151 \\
0.021\end{array}$ & $\begin{array}{l}0.785 \\
0.000\end{array}$ & $\begin{array}{r}-0.005 \\
0.937\end{array}$ & $\begin{array}{l}0.013 \\
0.844\end{array}$ & $\begin{array}{r}-0.222 \\
0.001\end{array}$ & 1.000 \\
\hline 16. Foreign exchange & $\begin{array}{l}0.189 \\
0.004\end{array}$ & $\begin{array}{l}0.238 \\
0.000\end{array}$ & $\begin{array}{l}0.160 \\
0.015\end{array}$ & $\begin{array}{r}-0.049 \\
0.454\end{array}$ & $\begin{array}{l}0.155 \\
0.018\end{array}$ & $\begin{array}{l}0.004 \\
0.956\end{array}$ & $\begin{array}{l}0.034 \\
0.611\end{array}$ & $\begin{array}{l}0.041 \\
0.538\end{array}$ & $\begin{array}{r}-0.054 \\
0.411\end{array}$ & $\begin{array}{l}0.306 \\
0.000\end{array}$ & $\begin{array}{r}-0.358 \\
0.000\end{array}$ & $\begin{array}{r}-0.036 \\
0.588\end{array}$ & $\begin{array}{l}0.024 \\
0.718\end{array}$ & $\begin{array}{l}0.122 \\
0.064\end{array}$ & $\begin{array}{r}-0.122 \\
0.063\end{array}$ \\
\hline
\end{tabular}

Notes: Significance levels are under the correlation coefficient. Spearman's rank correlations are preferred to Pearson's correlations for discrete and non-stationary variables 
Table 3. Number of observations and firms in combinations as used in Table 5

\begin{tabular}{|c|c|c|c|c|c|}
\hline $\begin{array}{l}\text { Combinations } \\
\text { as used in } \\
\text { Table V }\end{array}$ & $\begin{array}{l}\text { Description of } \\
\text { mutually exclusive } \\
\text { combinations }\end{array}$ & $\begin{array}{l}\mathrm{N} \text { of } \\
\text { obs. }\end{array}$ & $\begin{array}{l}\text { Number of obs. } \\
\text { (firms), with } \\
\text { controls }\end{array}$ & $\begin{array}{l}\text { Mean of investment } \\
\text { EUR m }\end{array}$ & $\begin{array}{l}\text { Mean of } T D_{i t} \text { on } \\
\text { a scale of } 0 \text { to } 1\end{array}$ \\
\hline$(1,1)$ & $\begin{array}{l}\text { Single controlling } \\
\text { shareholder, } \\
\text { RSPP board } \\
\text { member }\end{array}$ & 279 & $\begin{array}{c}72 \\
(18)\end{array}$ & $€ 617 \mathrm{~m}$ & 0.550 \\
\hline$(1,0)$ & $\begin{array}{l}\text { Single controlling } \\
\text { shareholder and } \\
\text { not an RSPP } \\
\text { board member }\end{array}$ & 790 & $\begin{array}{l}181 \\
(51)\end{array}$ & $€ 348 \mathrm{~m}$ & 0.568 \\
\hline$(0,1)$ & $\begin{array}{l}\text { Multiple } \\
\text { controlling } \\
\text { shareholders and } \\
\text { RSPP board } \\
\text { member }\end{array}$ & 266 & $\begin{array}{l}110 \\
(19)\end{array}$ & $€ 1,648 \mathrm{~m}$ & 0.532 \\
\hline$(0,0)$ & $\begin{array}{l}\text { Multiple } \\
\text { controlling } \\
\text { shareholders and } \\
\text { not an RSPP } \\
\text { board member }\end{array}$ & 196 & $\begin{array}{l}35 \\
(10)\end{array}$ & $€ 113 \mathrm{~m}$ & 0.481 \\
\hline $\begin{array}{l}\text { TOTAL for all } \\
4 \text { sub-groups }\end{array}$ & & $\begin{array}{c}1,531 \\
\text { obs. }\end{array}$ & $\begin{array}{l}398 \text { obs. (as per } \\
\text { fixed effects } \\
\text { model, Table V) } \\
\text { and } 99 \text { firms }\end{array}$ & & \\
\hline
\end{tabular}

Table 4. Cross-sectional results: explaining the mean of investment and Tobin's $Q$

\begin{tabular}{lcc}
\hline & $\begin{array}{c}\text { DV=Investment } \\
\text { OLS, cross-section } \\
\text { Coef. (se) }\end{array}$ & $\begin{array}{c}\text { DV=Tobin's } Q \\
\text { OLS, cross-section } \\
\text { Coef. (se) }\end{array}$ \\
\hline Sales & $0.938^{* * *}(0.075)$ & $-5.911+(3.496)$ \\
TD score & $0.708^{*}(0.297)$ & $-22.909^{* *}(8.464)$ \\
Degree centrality & $0.374^{*}(0.158)$ & $3.095(4.814)$ \\
EBIT margin & $-0.883^{* * *}(0.213)$ & $-5.622(16.837)$ \\
Debt & $0.109^{*}(0.046)$ & $-0.8202(1.447)$ \\
Foreign exchange & $-0.006(0.187)$ & $14.328^{* *}(5.277)$ \\
State owner & $-0.967+(0.523)$ & $-10.022(16.400)$ \\
RSPP membership & $-0.318(0.201)$ & $9.414+(5.627)$ \\
Single owner & $-0.039(0.190)$ & $7.364(5.211)$ \\
Investment & & $0.184(4.041)$ \\
Cash-flow & & $2.349(4.444)$ \\
Dividends $/$ Assets & 0.789 & $80.148(142.149)$ \\
$\mathrm{R}^{2}$ & 102 & 0.154 \\
Number of observations & & 93 \\
\hline Notes: ${ }^{2}<0.10,{ }^{*}<0.05,{ }^{* *} \mathrm{p}<0.01,{ }^{* * *} \mathrm{p}<0.001$. All variables are averaged over the studied period.
\end{tabular}


Table 5. Effect of governance and horizontal power on investment

\begin{tabular}{|c|c|c|}
\hline $\mathrm{DV}=\ln (\text { Investment })_{i t}$ & $\begin{array}{r}\text { Fixed effects } \\
\text { Coef. (se) }\end{array}$ & $\begin{array}{c}\text { GMM } \\
\text { Coef. (se) }\end{array}$ \\
\hline $\ln \left(\right.$ Investment $\left._{i, t-1}\right)$ & $\begin{array}{c}0.36 * * * \\
(0.07)\end{array}$ & $\begin{array}{c}0.95^{* * *} \\
(0.05)\end{array}$ \\
\hline$\Delta \ln \left(\right.$ Sales $\left._{i, t}\right)$ & $\begin{array}{l}0.33 * * \\
(0.12)\end{array}$ & $\begin{array}{c}3.48^{* * *} \\
(0.93)\end{array}$ \\
\hline$\Delta \ln \left(\right.$ Sales $\left._{i, t-1}\right)$ & $\begin{array}{c}0.33^{* * *} \\
(0.08)\end{array}$ & $\begin{array}{l}-0.18 \\
(0.16)\end{array}$ \\
\hline ect (Capital Stocki,t-2-Salesi,t-2) & $\begin{array}{c}-0.32^{* *} \\
(0.12)\end{array}$ & $\begin{array}{l}-0.14+ \\
(0.08)\end{array}$ \\
\hline $\ln \left(T D_{i t}\right) *$ central_firmsi & $\begin{array}{c}0.21 \\
(0.27)\end{array}$ & $\begin{array}{c}0.41 \\
(0.72)\end{array}$ \\
\hline $\ln \left(T D_{i t}\right) *$ peripheral_firms $s_{i}$ & $\begin{array}{l}0.33+ \\
(0.19)\end{array}$ & $\begin{array}{l}1.04+ \\
(0.53)\end{array}$ \\
\hline $\begin{array}{l}\text { Time Dummies 2002-2009 } \\
\mathrm{R}^{2} \\
\text { Number of observations } \\
\text { Diff-Hansen test } \\
\text { Diff-Hansen (p) } \\
\text { AR(1) } \\
\text { AR(1) (p) } \\
\text { AR(2) } \\
\text { AR(2) (p) }\end{array}$ & $\begin{array}{c}\text { Yes } \\
0.465 \\
399\end{array}$ & $\begin{array}{c}399 \\
4.40 \\
0.623 \\
-1.645 \\
0.0999 \\
-1.222 \\
0.222 \\
\end{array}$ \\
\hline
\end{tabular}

Notes: $+\mathrm{p}<0.10,{ }^{*} \mathrm{p}<0.05,{ }^{* *} \mathrm{p}<0.01,{ }^{* * *} \mathrm{p}<0.001$. We determine investment as $\ln$ (investmentit) $=\beta$ $+\beta_{1} *\left[\ln \left(\right.\right.$ capitalstock $\left._{,-2}\right)-\ln \left(\right.$ salesi,-2 $\left.\left._{i, 2}\right)\right]+\beta_{2} * \Delta \ln \left(\right.$ salesit $\left._{i}\right)+\beta_{3} * \Delta \ln \left(\right.$ sales $\left._{i,-1}\right)+\beta_{4} * \ln \left(\right.$ investment $\left._{i,-1}\right)+$

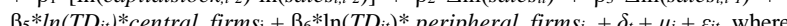

$\Delta$ refers to differences in variables; In is the natural logarithm; $\delta$ t are time dummies; $\mu$ i are time-invariant unobserved firm-level characteristics (fixed effects); and it is the error term. Central firms equals 1 if the firm's 2005 connectivity is greater than the mean and 0 otherwise. Peripheral firms equals 1 if firm's 2005 connectivity is lower than the mean and 0 otherwise. ect is error correction term. All variables except dummies are in natural logarithms. All standard errors are White's robust errors controlling for heteroscedasticity and panel-specific autocorrelation. The GMM estimator uses a one-step system of equations. We use the collapse option of xtabond2 as in Roodman (2009) to avoid instrument proliferation, a lag limit and a small sample adjustment to correct for the small number of obs. We trea lagged DV and TD variables as endogenous. AR(1) and AR(2) tests for first-order and second-order serial correlation in the first-differenced residuals detect no serial correlation. The Hansen test of overidentification is under the null that all instruments are valid and is robust.
Table 6. Effect of governance and horizontal power on Tobin's $Q$

\begin{tabular}{|c|c|c|}
\hline $\mathrm{DV}=Q_{i t}$ & $\begin{array}{c}\text { Fixed effects } \\
\text { Coef. (se) }\end{array}$ & $\begin{array}{c}\text { GMM } \\
\text { Coef. (se) }\end{array}$ \\
\hline \multirow[t]{2}{*}{$\ln \left(\right.$ Salesit $\left._{i}\right)$} & -0.15 & -2.83 \\
\hline & $(0.79)$ & $(2.53)$ \\
\hline \multirow[t]{2}{*}{$\ln ($ Debtit $)$} & -0.03 & -0.03 \\
\hline & $(0.02)$ & $(0.05)$ \\
\hline \multirow[t]{2}{*}{$\ln \left(\right.$ Investment $\left.t_{i t}\right)$} & -0.17 & -2.06 \\
\hline & $(0.26)$ & $(1.70)$ \\
\hline Dividend $_{i t} /$ Assetsit $_{\text {it }}$ & $\begin{array}{c}1.75 \\
(4.54)\end{array}$ & $\begin{array}{c}17.74 \\
(13.99)\end{array}$ \\
\hline $\ln \left(T D_{i t}\right) *$ central_firms $i$ & $\begin{array}{l}2.65+ \\
(1.50)\end{array}$ & $\begin{array}{c}9.58 \\
(11.27)\end{array}$ \\
\hline $\ln \left(T D_{i t}\right) *$ peripheral_firmsi & $\begin{array}{c}13.75^{* *} \\
(4.45)\end{array}$ & $\begin{array}{c}14.40^{* *} \\
(5.07)\end{array}$ \\
\hline Time Dummies 2002-2009 & $\begin{array}{c}\text { Yes } \\
0.652\end{array}$ & Yes \\
\hline Number of observations & & 313 \\
\hline Hansen test & & 0.59 \\
\hline Hansen (p) & & 0.444 \\
\hline $\mathrm{AR}(1)$ & & -0.0315 \\
\hline $\mathrm{AR}(1)(\mathrm{p})$ & & 0.975 \\
\hline $\mathrm{AR}(2)$ & & -0.565 \\
\hline $\operatorname{AR}(2)(\mathrm{p})$ & & 0.572 \\
\hline
\end{tabular}

$\beta_{2} * \ln \left(\right.$ debt $\left._{i t}\right)+\beta_{3} * \ln \left(\right.$ investment $\left._{i t}\right)+\beta_{4} *\left(\frac{\text { dividend }_{\text {assets }}}{i, t}+\beta_{5} * \ln \left(T D_{i t}\right) *\right.$ central_firms $_{i}+\beta_{6} *$

$\ln \left(T D_{i t}\right) *$ peripheral_firms $s_{i}+\delta_{t}+\mu_{i}+\varepsilon_{i t}$ where central firms variable equals 1 if the firm's 2005 connectivity is greater than the mean and 0 otherwise. Peripheral_firms var. equals 1 if firm's 2005 connectivity is lower than the mean and 0 otherwise. All standard errors are White's robust errors controlling for heteroscedasticity and panel-specific autocorrelation. The GMM estimator uses a one-step system of equations. We use the collapse option of xtabond2 as in Roodman (2009), a lag limit and a small sample adjustment to correct for the small number of obs. We assume that TD and its interactions are endogenous. AR(1) and AR(2) are tests for first-order and secondorder serial correlation in the first-differenced residuals under the null of no serial correlation. AR(2) detects no autocorrelation in levels. The Hansen test of over- identification is under the null that all instruments are valid. 
Table 7. Effect of governance and vertical power on investment $\mathrm{DV}=\ln (\text { Investment })_{i}$

In(Investment $\left.t_{,-1}\right)$

$0.36^{* * *}$

$(0.07)$

0.34

$\Delta \ln (\text { Sales } i, t)^{\prime}$

$\Delta \ln ($ Salesi,-1 $)$

ect (Capital Stock $k_{i,-2-S a l e s} i_{i,-2}$ )$$
\begin{array}{r}
(0.14) \\
0.34 * * *
\end{array}
$$

$0.34^{* * *}$
$(0.08)$

$-0.32 * *$

$(0.12)$

0.12

$\ln \left(T D_{i t}\right) *(1,1)$

single owner and RSPP member)

(0.29)

$\ln \left(T D_{\text {it }}\right) *(1,0)$

(single owner, not RSPP member)

$\ln \left(T D_{i t}\right) *(0,1)$

(multiple owners, RSPP member)

$\ln \left(T D_{i t}\right) *(0,0)$

(multiple owners, not RSPP member)

Time dummies 2002-2009

Number of observations

Diff-Hansen test

Diff-Hansen(p)

AR(1)

AR(1) (p)

$\operatorname{AR}(2)$

AR(2) (p)

$0.37 *$

(0.15)

0.35

(0.44)

$-0.20$

(0.78)

Yes

0.468
398

GMM

Coeff. (se)

0.86***

(0.07)

2.39***

$(0.65)$

0.02

(0.17)

$-0.20$

$(0.13)$

$1.48^{*}$

(0.67)

$1.18 *$

$(0.59)$

$-0.07$

$(0.59)$
2.75

(1.74)

Yes

(p) -1.574

as $\ln \left(\right.$ investment $\left._{i t}\right)=\beta_{0}+\beta_{1} *\left[\ln \left(\right.\right.$ capitalstock $\left._{,-2}\right)-\ln \left(\right.$ sales $\left.\left._{i,-2}\right)\right]+\beta_{2} * \Delta \ln \left(\right.$ sales $\left._{i t}\right)+\beta_{3} * \Delta \ln \left(\right.$ sales $\left._{i,-1}\right)+$ $\beta_{4} * \ln \left(\right.$ investment $\left._{i,-1}\right)+\beta_{5} * \ln \left(T D_{i t}\right) *(\text { single_owner and RSPP_member })_{i}+\beta_{6} * \ln \left(T D_{i t}\right) *($ single owner, not RSPP member $)_{i}+\beta_{7}^{*} \ln \left(T D_{i t}\right) *(\text { multiple owners, RSPP member })_{i}+\beta_{8}^{*} \ln \left(T D_{i t}\right)^{*}($ multiple owners, not RSPP member $)_{i}+\delta_{t}+\mu_{i}+\varepsilon_{i t}$ where

$\Delta$ refers to differences in variables; In is the natural logarithm; $\delta t$ are time dummies; $\mu$ a are time-invariant

unobserved firm-level characteristics (fixed effects); and $\varepsilon$ it is the error term. ect or ${ }_{\left[\ln \left(c a p i t a l s t o c k_{t-2}\right) \text { - }\right.}$ $\ln \left(\right.$ sales $\left.\left._{i,-2}\right)\right]$ is the error correction term. All variables except dummies are in natural logarithms. All standard errors are White's robust errors system of equations. We use the collapse option of xtabond2 as in Roodman (2009) to avoid instrument proliferation, a lag limit and a small sample adjustment to correct for the small number of obs. We treat lagged DV and TD variables as endogenous. AR(1) and AR(2) tests for first-order and second-order seria correlation in the first-differenced residuals detect no serial correlation. The Hansen test of overidentification is under the null that all instruments are valid and is robust.
Table 8. Effect of governance and vertical power on Tobin's Q

\begin{tabular}{|c|c|c|}
\hline $\mathrm{DV}=Q_{i t}$ & $\begin{array}{c}\text { FE } \\
\text { Coeff. (se) } \\
\end{array}$ & $\begin{array}{c}\text { GMM } \\
\text { Coeff. (se) }\end{array}$ \\
\hline $\ln \left(\right.$ Sales $\left._{i t}\right)$ & $\begin{array}{c}0.92 \\
(0.83)\end{array}$ & $\begin{array}{l}-4.57 \\
(4.46)\end{array}$ \\
\hline $\ln \left(\right.$ Debt $\left._{i t}\right)$ & $\begin{array}{c}0.00 \\
(0.01)\end{array}$ & $\begin{array}{c}0.02 \\
(0.06)\end{array}$ \\
\hline $\ln \left(\right.$ Investment $\left._{i t}\right)$ & $\begin{array}{l}-0.11 \\
(0.12)\end{array}$ & $\begin{array}{l}-1.05 \\
(1.14)\end{array}$ \\
\hline Dividend $_{i t} /$ Assets $_{i t}$ & $\begin{array}{c}4.44 \\
(3.76)\end{array}$ & $\begin{array}{c}19.18 \\
(15.96)\end{array}$ \\
\hline $\begin{array}{l}\ln \left(T D_{i t}\right) *(1,1) \\
\text { (single owner and RSPP member) }\end{array}$ & $\begin{array}{c}17.39 * * * \\
(2.76)\end{array}$ & $\begin{array}{c}14.54 * * * \\
(3.95)\end{array}$ \\
\hline $\ln \left(T D_{i t}\right) *(1,0)$ & 0.74 & $12.54+$ \\
\hline (single owner, not RSPP member) & $(0.61)$ & $(7.00)$ \\
\hline $\ln \left(T D_{i t}\right) *(0,1)$ & $0.92+$ & -4.6 \\
\hline (multiple owners, RSPP member) & $(0.55)$ & $(10.07)$ \\
\hline $\begin{array}{l}\ln \left(T D_{i t}\right) *(0,0) \\
\text { (multiple owners, not RSPP member) }\end{array}$ & $\begin{array}{l}1.12 \\
(1.74)\end{array}$ & $\begin{array}{c}12.81 \\
(10.77)\end{array}$ \\
\hline Time dummies 2002-2009 & Yes & Yes \\
\hline $\mathrm{R}^{2}$ & 0.805 & \\
\hline Number of observations & 312 & 312 \\
\hline Hansen test & & 8.16 \\
\hline Hansen (p) & & 0.772 \\
\hline $\operatorname{AR}(1)$ & & 0.972 \\
\hline $\operatorname{AR}(1)(p)$ & & 0.331 \\
\hline $\operatorname{AR}(2)$ & & -1.557 \\
\hline $\operatorname{AR}(2)(p)$ & & 0.119 \\
\hline
\end{tabular}

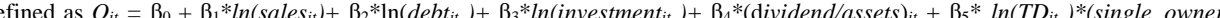
and RSPP_member $)_{i}+\beta_{6} * \ln \left(T D_{i t}\right)^{*}(\text { single owner, not RSPP member })_{i}+\beta_{7}^{*} \ln \left(T D_{i t}\right) *(\text { multiple owners, RSPP member })_{i}+\beta_{8} *$ $\ln \left(T D_{i t}\right)^{*}$ (multiple owners, not RSPP member $)_{i}+\delta_{t}+\mu_{i}+\varepsilon_{i t}$

All standard errors are White's robust errors controlling for heteroscedasticity and panel-specific autocorrelation.

The GMM estimator uses a one-step system of equations. We use the collapse option of xtabond2 as in Roodman (2009), a lag limit and a small sample adjustment to correct for the small number of obs. We assume that TD and its interactions are endogenous. AR(1) and AR(2) are tests for first-order and second-order serial correlation in the first-differenced residuals under the null of no serial correlation. AR(2) detects no autocorrelation in levels. The Hansen test of over- identification is under the 
Appendices with Supplementary Analysis

Table A1. Interaction of state owned firms with central/ peripheral networks

\begin{tabular}{|c|c|c|c|c|}
\hline & $\ln$ (Investment) & $\ln$ (Investment) & Tobin's Q & Tobin's Q \\
\hline VARIABLES & FE & GMM & $\mathrm{FE}$ & GMM \\
\hline $\ln \left(\right.$ Investment $\left._{i,-1}\right)$ & $\begin{array}{r}0.36^{* * *} \\
(0.07)\end{array}$ & $\begin{array}{r}0.96^{* * *} \\
(0.05)\end{array}$ & & \\
\hline$\Delta \ln \left(\right.$ Sales $\left._{i, t}\right)$ & $\begin{array}{r}0.37 * * \\
(0.12)\end{array}$ & $\begin{array}{r}3.14^{* * *} \\
(0.80)\end{array}$ & & \\
\hline$\Delta \ln \left(\right.$ Sales $\left._{i,-1-1}\right)$ & $\begin{array}{r}0.35^{* * *} \\
(0.07)\end{array}$ & $\begin{array}{c}-0.17 \\
(0.15)\end{array}$ & & \\
\hline ect (Capital Stock ${ }_{i, t-2-}$ Sales $_{i,-2}$ ) & $\begin{array}{r}-0.33^{* *} \\
(0.11)\end{array}$ & $\begin{array}{c}-0.16+ \\
(0.08)\end{array}$ & & \\
\hline $\ln \left(T D_{i t}\right){ }^{*}$ central_firms ${ }_{i}$ *private_firms $s_{i}$ & $\begin{array}{c}-0.92 * \\
(0.40)\end{array}$ & $\begin{array}{r}0.89 \\
(0.65)\end{array}$ & $\begin{array}{r}-0.91 \\
(2.34)\end{array}$ & $\begin{array}{r}0.64 \\
(20.34)\end{array}$ \\
\hline $\ln \left(T D_{i t}\right) *$ peripheral_firms ${ }^{*}$ private_firms $i$ & $\begin{array}{l}0.31+ \\
(0.19)\end{array}$ & $\begin{array}{l}1.07 * \\
(0.52)\end{array}$ & $\begin{array}{r}13.76^{* *} \\
(4.44)\end{array}$ & $\begin{array}{r}11.54+ \\
(6.11)\end{array}$ \\
\hline $\ln \left(T D_{i t}\right) * c e n t r a l \_f i r m s_{i} *$ state_firms $i$ & $\begin{array}{r}0.42 \\
(0.33)\end{array}$ & $\begin{array}{r}0.38 \\
(0.63)\end{array}$ & $\begin{array}{l}2.85+ \\
(1.68)\end{array}$ & $\begin{array}{r}57.9 \\
(47.58)\end{array}$ \\
\hline $\ln \left(\right.$ Salesit $\left._{i t}\right)$ & & & $\begin{array}{c}-0.07 \\
(0.88)\end{array}$ & $\begin{array}{r}0.78 \\
(2.33)\end{array}$ \\
\hline $\ln \left(D_{e b t}{ }_{i t}\right)$ & & & $\begin{array}{r}-0.03 \\
(0.02)\end{array}$ & $\begin{array}{r}-0.04 \\
(0.16)\end{array}$ \\
\hline $\ln ($ Investmentit) & & & $\begin{array}{r}-0.2 \\
(0.27)\end{array}$ & $\begin{array}{r}-3.84 \\
(3.28)\end{array}$ \\
\hline Dividend $_{i t} /$ Assetsit & & & $\begin{array}{r}1.7 \\
(4.57)\end{array}$ & $\begin{array}{c}-65.94 \\
(69.78)\end{array}$ \\
\hline Constant & $\begin{array}{r}5.58^{* * *} \\
(0.60)\end{array}$ & & $\begin{array}{r}12.1 \\
(7.67)\end{array}$ & \\
\hline Observations & 398 & 398 & 312 & 312 \\
\hline R-squared & 0.474 & & 0.653 & \\
\hline Number of firms & 98 & 98 & 86 & 86 \\
\hline
\end{tabular}

Notes

Robust standard errors in parentheses.

*** $\mathrm{p}<0.001,{ }^{* *} \mathrm{p}<0.01,{ }^{*} \mathrm{p}<0.05,+\mathrm{p}<0.10$

Year dummies included, state-owned and peripheral firms category is omitted due to limited observations 
Table A2. Effect of TD and single and/or state owners on investment and Tobin's Q

\begin{tabular}{|c|c|c|c|c|}
\hline VARIABLES & $\begin{array}{c}\ln \text { (Investment) } \\
\text { FE }\end{array}$ & $\begin{array}{l}\ln \text { (Investment) } \\
\text { GMM }\end{array}$ & $\begin{array}{l}\text { Tobin's Q } \\
\text { FE }\end{array}$ & $\begin{array}{c}\text { Tobin's Q } \\
\text { GMM }\end{array}$ \\
\hline $\ln \left(\right.$ Investment $\left.t_{i,-1}\right)$ & $\begin{array}{l}0.37 * * * \\
(0.07)\end{array}$ & $\begin{array}{c}0.89 * * * \\
(0.05)\end{array}$ & & \\
\hline$\Delta \ln \left(\right.$ Sales $\left._{i, t}\right)$ & $\begin{array}{l}0.37^{* *} \\
(0.14)\end{array}$ & $\begin{array}{c}2.53^{* * *} \\
(0.57)\end{array}$ & & \\
\hline$\Delta \ln ($ Salesi,t-1)$)$ & $\begin{array}{l}0.34^{* * *} \\
(0.08)\end{array}$ & $\begin{array}{c}0 \\
(0.14)\end{array}$ & & \\
\hline ect (Capital Stocki,t-2-Salesi,t-2) & $\begin{array}{c}-0.32 * * \\
(0.12)\end{array}$ & $\begin{array}{l}-0.13 \\
(0.09)\end{array}$ & & \\
\hline $\begin{array}{l}\ln \left(T D_{i t}\right) *(1,1) \\
\text { (single state owner ) }\end{array}$ & $\begin{array}{l}0.47^{*} \\
(0.20)\end{array}$ & $\begin{array}{l}1.33^{*} \\
(0.59)\end{array}$ & $\begin{array}{c}2.65 \\
(1.82)\end{array}$ & $\begin{array}{l}14.89+ \\
(8.49)\end{array}$ \\
\hline $\begin{array}{l}\ln \left(T D_{i t}\right) *(1,0) \\
\text { (single non-state owner) }\end{array}$ & $\begin{array}{c}0.19 \\
(0.21)\end{array}$ & $\begin{array}{l}1.56 * * \\
(0.57)\end{array}$ & $\begin{array}{c}14.94 * * * \\
(3.94)\end{array}$ & $\begin{array}{l}10.47^{*} \\
(4.05)\end{array}$ \\
\hline $\begin{array}{l}\ln \left(T D_{i t}\right)^{*}(0,1) \\
\text { (multiple owners, state) }\end{array}$ & $\begin{array}{c}0.39 \\
(0.64)\end{array}$ & $\begin{array}{c}-0.1 \\
(0.60)\end{array}$ & $\begin{array}{c}2.04 \\
(1.34)\end{array}$ & $\begin{array}{l}-1.08 \\
(6.76)\end{array}$ \\
\hline $\begin{array}{l}\ln \left(T D_{i t}\right) *(0,0) \\
\text { (multiple non- state owners) }\end{array}$ & $\begin{array}{c}0.1 \\
(0.37)\end{array}$ & $\begin{array}{c}0.85 \\
(0.54)\end{array}$ & $\begin{array}{l}1.94+ \\
(1.00)\end{array}$ & $\begin{array}{l}5.09+ \\
(2.74)\end{array}$ \\
\hline $\ln \left(\right.$ Sales $\left._{i t}\right)$ & & & $\begin{array}{c}0.38 \\
(1.00)\end{array}$ & $\begin{array}{l}-3.68 \\
(3.43)\end{array}$ \\
\hline $\ln \left(\right.$ Debt $\left._{i t}\right)$ & & & $\begin{array}{l}-0.01 \\
(0.02)\end{array}$ & $\begin{array}{l}-0.05 \\
(0.06)\end{array}$ \\
\hline $\ln \left(\right.$ Investment $\left.{ }_{i t}\right)$ & & & $\begin{array}{c}0.01 \\
(0.20)\end{array}$ & $\begin{array}{l}-1.23 \\
(1.14)\end{array}$ \\
\hline Dividend $_{i t} /$ Assets $_{i t}$ & & & $\begin{array}{l}-0.09 \\
(4.64)\end{array}$ & $\begin{array}{c}24.81 \\
(20.09)\end{array}$ \\
\hline Constant & $\begin{array}{c}5.54 * * * \\
(0.61) \\
\end{array}$ & & $\begin{array}{c}4.6 \\
(8.66) \\
\end{array}$ & \\
\hline Observations & 398 & 398 & 312 & 312 \\
\hline R-squared & 0.468 & & 0.701 & \\
\hline Number of firms & 98 & 98 & 86 & 86 \\
\hline
\end{tabular}


Table A3. Financial constraints.

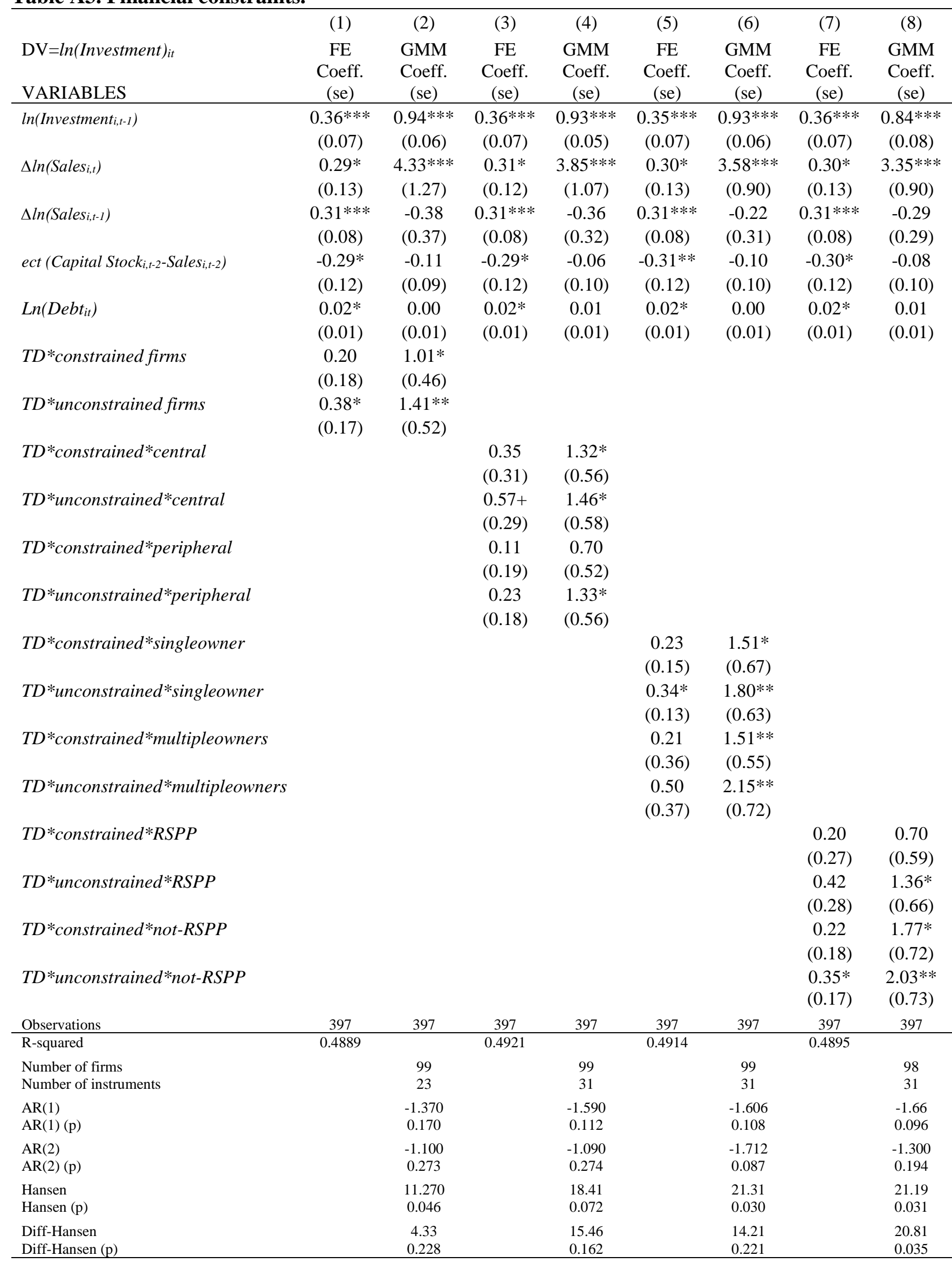

Robust standard errors in parentheses, Year dummies included

*** $\mathrm{p}<0.001,{ }^{* *} \mathrm{p}<0.01,{ }^{*} \mathrm{p}<0.05,+\mathrm{p}<0.1$ 